\title{
REPORT
}

ON THE

\section{INJURIOUS INSECTS}

AND Orture

\author{
ANIMALS
}

\author{
OBSERVED IN THE MIDLAND COUNTIES \\ DURING 1907.
}

BY

WALTER E. COLLINGE, M.Sc., F.L.S., F.E.S.,

Foreign Member of the Association of Economic Entomologists, Washingion, U.S.A. ;

Honorary Secrelary of the Associalion of Economic Blologists; Editor of the

"Journal of Economic Biology" : Henorary Consulting Zoologist to the

Land Agents' Society, and the Midland Reafforesting Association;

Honorary Consulting Biologist to the Warwickshire Agricultural

Sociely; and Special Lecturer or Economic Zoology

in the Untversity of Birmingham.

\section{FIFTH REPORT.}

ILLUSTRATED.

BIRMINGHAM :

CORNISH BROS., LTD.

1908.

[ALL, RIGHTS RESERVED.]

PRICE 2S. 6d. 


\section{Sp $\mid$}

fron

The
Reliak

\section{chines}

\section{E25.}

RAYER is sy to Work.

\section{MACHINES BUILT TO ORDER.}

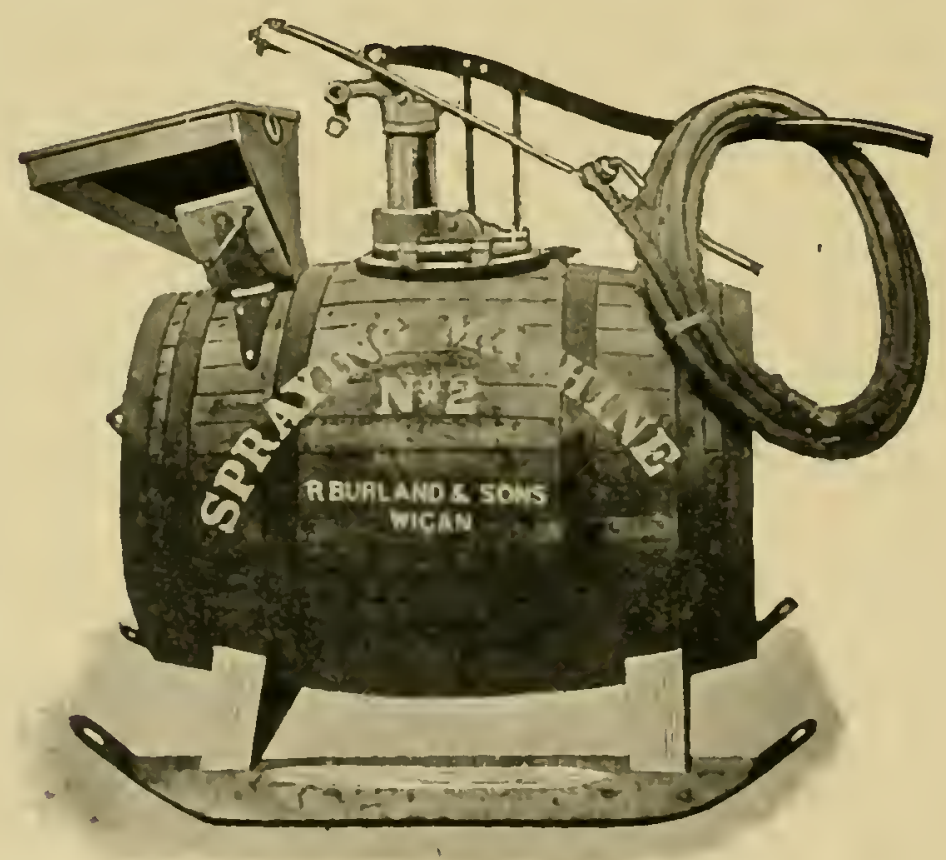

\section{A "BURLAND" SPRAYER will} increase the value of your orchard.

Makers,

\section{R. BURLAND \& SONS, WIGAN.} SEND FOR II.L.USTRATED LIST. 


\section{CLAY'S FERTILIZER THE FOOD OF LIFE FOR PLANTS.}

It feeds the Plant, and promotes Healthy Foliage, Wealth of Flowers and Fruit, and Abundance of Vegetables.

\section{IT IS SAFE, QUICK, AND LASTING.}

It is used by the Leading Growers, Government and Local Authorities, and Horticulturists throughout the World.

Sold everywhere in $6 \mathrm{~d}$. and $1 \mathrm{~s}$. Tins, and in Sealed Bags :-7 lbs., 2s. 6d. ; 14 lbs., 4s. 6d.; 28 lbs., 7s. $6 \mathrm{~d}$. 56 lbs., 12s. 6d.; 112 lbs., 20s. Or direct from the Works, Carriage Paid in the United Kingdom for Cash with Order (except 6d. Tins.)

EVERY TIN, BAG, \& SEAL BEARS THE TRADE MARK,

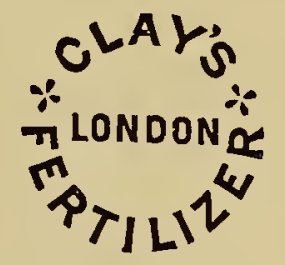

TRADE MARK
THE ONLY GUARANTEE OF GENUINENESS.

FULL DIRECTIONS FOR USE APPEAR IN

\section{CLAY'S SUCCESSFUL GARDENING.}

Illustrated, Enlarged, and Revised. Bound in Cloth.

Price 9d. post free, or of Seedsmen.

Its contributions are by the ablest writers of the day. It is an up-todate work dealing with the Culture of Flowers, Fruits, and Vegetables, and includes articles on Exhibiting, Judging, and Growing for Market.

Write for PRICE LIST of Manures, Chemicals, and Sundries. Best only.

\section{CLAY \& SON,}

MANURE MANUFACTURERS, BONE CRUSHERS, \&C., STRATFORD, LONDON, E. 


\section{THE \\ COUNTY}

ESTABLISHED 1896.

\section{Live Stock Insurance Association, Ltd., YORK.}

JOHN HETHERTON, F.S.A.A., MAMAGIMO DIAECTOR.

\section{Over $£ 70,000$ paid in Claims. Assets exceed $£ 10,000$}

HORSES used for Private, Professional, Furming and Trade purposes insured for Full Value against Death from Accident or Disease, with Compensation during Disablement.

STALLIONS insured against Death, with Compensation for Disabtement through Accident or Disease during the Travelling Scason. Policies cover risks excluded by other Companies. Service Registers and Pedigree Cards supplied free. A prize is given for the best Foal by each stallion insured.

IN-FOAL MARES and UNBORN FOALS insured. Advantages given which are not ofiered by any other Company.

BULLS, COWS, SHEEP and PIGS insured.

PEDIGREE DOGS and valuable DOGS USED FOR SPORTING PURPOSES instured. Bitches are insured against whelping risks.

See Prospectuses and Testimonlals from every district.

PRIZES GIVEN AT SHOWS.

\section{The FARMERS'}

Fire and Accident Insurance Association, Ltd.

FIRE Insurance at Non-tariff Rates.

WORKMEN'S COMPENSATION, (including Domestic Servants') Insulance at lowest Ratles.

\section{ACCIDENT AND SICKNESS}

Insurance Gircillerl Bencefits.
BURGLARY Insurance.

(lucluding Theit by Servants.)

DRIVERS' ACCIDENTS and VEHICLE Insurance.

The HOUSEHOLDER'S COMPREHENSIVE POLICY grives special adrantages al reduced r:all@.

\section{THE FARMER'S DIARY,}

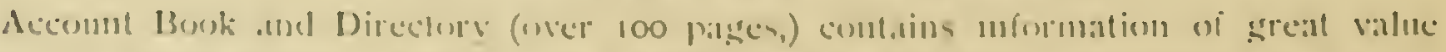

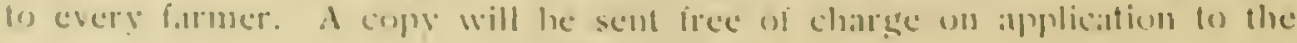
Hesal Office.

FARMERS AND OTHERS WANTED AS AGENTS. 



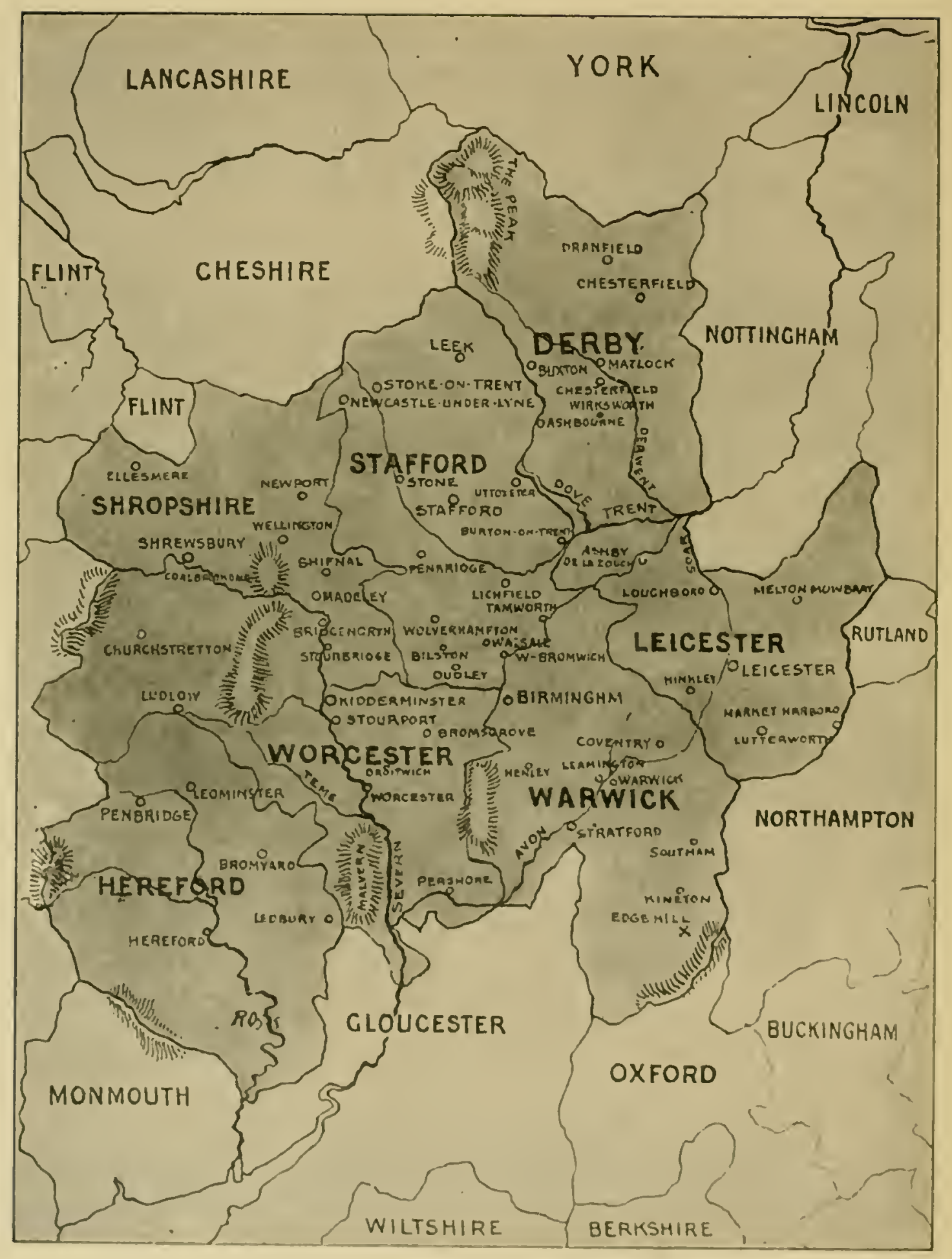

Map Showing Midland Counties. 


\title{
REPORT
}

\section{ON THE \\ INJURIOUS INSECTS}

AND OTHER

\section{ANIMALS}

\author{
OBSERVED IN THE MIDLAND COUNTIES \\ DURING 1907.
}

BY

WALTER E. COLLINGE, M.Sc., F.L.S., F.E.S.,

Foreign Member of the Association of Economic Enlomologists, Washington, U.S.A.;

Honorary Secretary of the Association of Economic Biologists; Editor of the

"Journal of Economic Biology"; Honorary Consulting Zoologist to the

Land Agents' Society, and the Midland Reafforesting Association;

Honorary Consulting Biologist to the Warwickshire Agricultural

Society; and Special Leclurer on Economic Zoology

in the University of Birmingham.

\section{FIFTH REPORT.}

\section{ILLUSTRATED.}

BIRMINGHAM :

CORNISH BROS., LTD.

1908.

[ALL RIGHTS RESERVED.] 


$$
\begin{aligned}
& 53605 \\
& 6766
\end{aligned}
$$




\section{PREFACE.}

IN issuing a Fifth Report on the Injurious Insects and other Animals of the Midland Counties of England, received from various correspondents during the year 1907 , it is again my pleasant duty to acknowledge a Grant of $f_{0}$ Io from the County Councils of Derbyshire, Leicestershire, and Warwickshire, aiding the publication of this Report.

As a Report on the Injurious Animals of the Midland Counties, this will be the last I shall issue. As is well known, I have felt compelled to resign my position in the University of Birmingham owing to the lack of adequate financial support and remuneration. Since that date I have been offered and have accepted the Directorship of the Cooper Research Laboratory, Berkhamsted, where, with a full and capable staff, a wider field for work presents itself, but my services will be as freely at the command of Midland agriculturists and fruit-growers as in the past.

Further Reports will be of a more comprehensive nature, and will include accounts of Injurious Fungi, Animal Parasites, and Animal Diseases, in addition to the subjects dealt with in the present series of Reports.

It is my privilege and pleasant duty to once again tender my thanks to that large band of Midland agriculturists and horticulturists, who have so willingly afforded me assistance, and to whom, I trust, I shall continue to be of some service in return.

I am indebted to the courtesy of the Controller of $\mathrm{His}$ Majesty's Stationery Office and the Secretary of the Board of Agriculture and Fisheries for permission to use Figures 4, 7, and 9, all of which are from illustrations which have appeared in the Board's leaflets.

WALTER E. COLLINGE.

The University Department of Economic Zoology,

55, Newhall Street, Birmingham, Fantary 3rst, 1908. 



\section{CONTENTS.}

PAGE

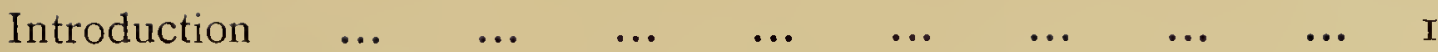

Investigations.

Orchard Inspection.

Publications. $\quad 3$

Lectures and Addresses.

Injurious Fungi. (Illustration.) 4

Report on Experiments with Insecticides and Fungicides.

$\begin{array}{lllllllll}\text { (Illustration.) } & \ldots & \ldots & \ldots & \ldots & \ldots & \ldots & \ldots & 7\end{array}$

Report on Experiments with the Black-Currant Gall-Mite, Eriophyes

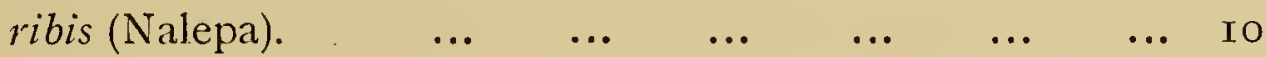

Report on Experiments with Eelworms. The Fumigation of the

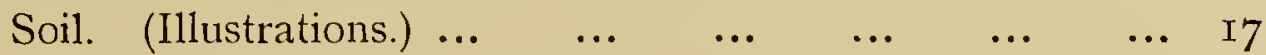

Report upon Insect Parasites of Insects. $\quad \ldots \quad \ldots \quad \ldots \quad \ldots \quad \ldots \quad 20$

The Gooseberry Gall-Mite. Eriophyes grossulariae, Cllge. ... ... 20

The Bulb Mite. Rhizoglyphus echinopus, F. \& R. $\quad \ldots \quad \ldots \quad \ldots \quad$.. 20

The Harvest Bug. Leptus autumnalis, Shaw. $\quad \ldots \quad \ldots \quad \ldots \quad \ldots \quad$ I

The Pea and Bean Thrips. Thrips pisivora, Westwood. ... $\quad \ldots \quad 2$ I

The Brown Scale. Lecaninm hemisphericum, Targ.-Tozz. ... $\quad \ldots \quad 22$

The Brown Currant Scale. Lecaninm persicae (Geoff.) var. corylii

$\begin{array}{llllllllll}(\operatorname{Linn} .) & \ldots & \ldots & \ldots & \ldots & \ldots & \ldots & \ldots & \ldots & 22\end{array}$

Mealy Bugs. Dactylopins citri (Risso), and D.longispinns, Targ.-Tozz.

$\begin{array}{lllllllll}\text { (Illustration.) } & \ldots & \ldots & \ldots & \ldots & \ldots & \ldots & \ldots & 23\end{array}$

The Felted Beech Coccus. Cyrptococcus fagi, Barensp. $\quad \ldots \quad \ldots \quad \ldots 23$

The Felted Ash Coccus. Apterococcus fraxini (Newstead). _ ... 23 
CONTENTS.

PAGE

The Hop Aphis. Phorodon hmmmli, Schrank, $\quad \ldots \quad \ldots \quad \ldots \quad \ldots \quad 2.3$

The Willow Aphis. Lachmms imimalis, Fonsc. $\quad \ldots \quad \ldots \quad \ldots \quad \ldots \quad$ if

The Moolly Aphis. Schizoncura lanigcra, Hausm. (Illustration.)... $2 f$

The Fruit Tree Root Louse. Schizoncura fodicus, Bucliton. . . 29

The Apple Sucker. Pṣlla mali, Schm. (Illustration.) $\ldots$... 29

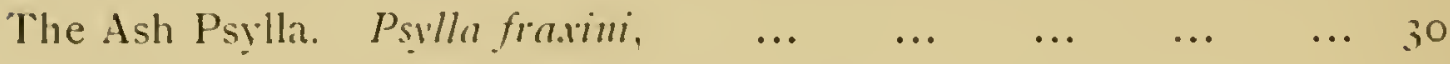

The May Bug. Phylloperlha horticola, Limn. $\quad \ldots \quad \ldots \quad \ldots \quad \ldots \quad 30$

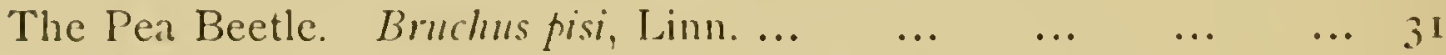

The Apple Blossom Weevil. Anthonomms pomormm, Linn... ... 31

The Cabbage Gall Weevil. Couthorhunchus sulcicollis, Gyll. .. 31

The Tumip Seed Weevil. Comlhorlynchus assimilis, Payl. $\quad \ldots \quad 32$

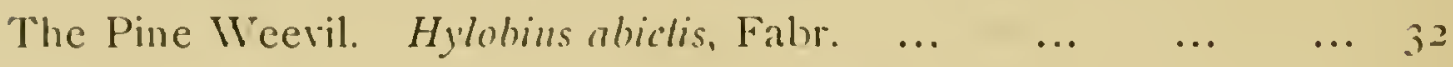

The Osier Teevil. Cryplorhenchus lapalhi, Linn, $\ldots \quad \ldots \quad \ldots \quad \ldots \quad 33$

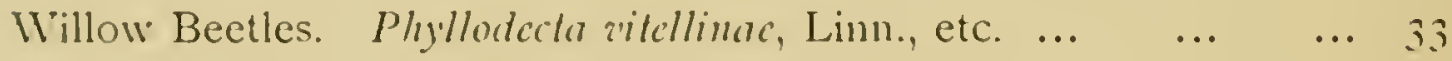

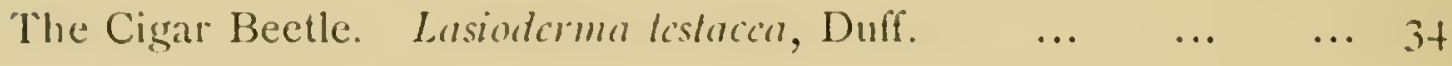

The Wood Leopard Moth. Zenzera acsuli, Limn. ... $\quad \ldots \quad \ldots \quad \ldots 5$

The Garden Swift Moth. Hefialus lupulimus, Limn... $\quad \ldots \quad \ldots \quad$.. 35

The Lappet Moth. Lasiocumpa quorcifoliu, Linn. $\quad \ldots \quad \ldots \quad \ldots \quad \ldots \quad$ 35

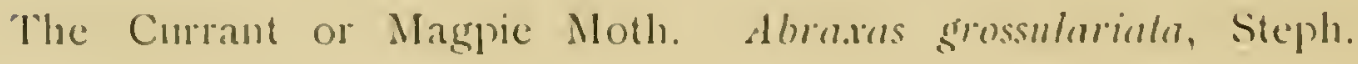
$\begin{array}{lllllllll}\text { (1llustration.) } & \ldots & \ldots & \ldots & \ldots & \ldots & \ldots & \ldots & \end{array}$

The Winter Moth. Chcimatobia brumala, Linn. (Illustration.) .. 36

The Turnip Dart Moth. Agrolis segrefmm, Schiff. $\quad \ldots \quad \ldots \quad \ldots \quad \ldots \quad$ it

The Heart and Datrt Moth. Astolis colommationis, Limn. ... ... is

The Great Vellow Underwing Moth. Trifhmena frommber, Limm.

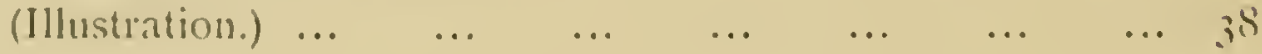


CONTENTS.

PAGE

The Apple Leaf Miner. Lyonetia clerckella, Linn. ... $\quad \ldots \quad \ldots \quad \ldots 39$

The Apple Ermine Moth. Hyponomenta malinella, Zell. (Illustra$\begin{array}{llllllllll}\text { tion.) } & \ldots & \ldots & \ldots & \ldots & \ldots & \ldots & \ldots & \ldots & 39\end{array}$

$\begin{array}{llllll}\text { The Raspberry Gall Fly. Lasioptera rubi, Schrk. } & \ldots & \ldots & \ldots & 4 \mathrm{I}\end{array}$

The Ash Cauliflower Gnat. Cecidomyia frawinella, Meade. $\quad \ldots \quad$ 4I

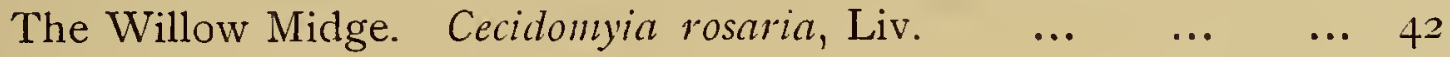

$\begin{array}{lllllll}\text { The Pear Midge. Diplosis pyrivora, Riley. } & \ldots & \ldots & \ldots & \ldots & 4^{2}\end{array}$

$\begin{array}{llllll}\text { The Onion Fly. Phorbia ceparum, Bouché.... } & \ldots & \ldots & \ldots & 42\end{array}$

$\begin{array}{llllllll}\text { The Frit Fly. Oscinus frit, Linn. } & \ldots & \ldots & \ldots & \ldots & \ldots & 43\end{array}$

$\begin{array}{lllllll}\text { The Carrot Rust Fly. Psila rosae (Fabr.). } & \ldots & \ldots & \ldots & \ldots & +3\end{array}$

$\begin{array}{lllllll}\text { The Gout Fly. Chlorops taeniopus, Meig. } & \ldots & \ldots & \ldots & \ldots & +4\end{array}$

The Pea Leaf Miner. Pliytomyza pisi, Kalt... $\quad \ldots \quad \ldots \quad \ldots \quad \ldots 5$

The Orchid Midge. Isosoma orchidearnm, Westwood. $\quad \ldots \quad \ldots \quad 45$

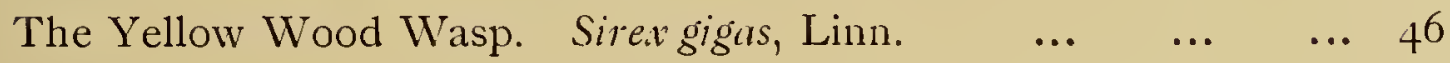

$\begin{array}{lllllll}\text { The Pear Sawfly. Tentluedo cerasi, Linn. } & \ldots & \ldots & \ldots & \ldots & 46\end{array}$

$\begin{array}{llllllll}\text { Parasitic Diseases of Animals } \ldots & \ldots & \ldots & \ldots & \ldots & \ldots & 48\end{array}$

Red Worms. Sclerostomum armatum, Duj. $\quad \ldots \quad \ldots \quad \ldots$

The Liver Fluke. Fasciola (Distomum) hepatica (Linn.). 49

The "Gid" Parasite. Taenia caenurus, Kuch. $\quad \ldots \quad \ldots \quad$ 50

Scabies (Mange) in Horses and Dogs. $\quad \ldots \quad \ldots \quad \ldots \quad$ 5

The Warble Fly. Hypoderma lineata (Villers). $\ldots . \quad \ldots \quad 52$

Hypoderma bovis (De Geer). $\ldots \quad \ldots \quad 5^{2}$

The Sheep Fly. Lucilia sericata (Meigen). $\quad \ldots \quad \ldots \quad 54$

Lucilia caesar (Linn.). ... $\quad \ldots \quad \ldots \quad 54$

Appendix A. Instructions for using Hydrocyanic Acid Gas and

$\begin{array}{lllllll}\text { Bisulphide of Carbon. } & \ldots & \ldots & \ldots & \ldots & \ldots & 56\end{array}$

$\begin{array}{llllllllll}\text { Appendix B. } & \ldots & \ldots & \ldots & \ldots & \ldots & \ldots & \ldots & \ldots & 57\end{array}$ 



\section{LIST OF ILLUSTRATIONS.}

PAGE

Map showing Midland Counties. Frontispiece.

Fig. I. Fruit Bodies of Polyporus squamosus on Elm. $\quad \ldots \quad$... 6

$\begin{array}{lllllll}\text { Fig. } & \text { 2. Unsprayed apples attacked by Scab. } & \ldots & \ldots & \ldots & 8\end{array}$

$\begin{array}{lllllll}\text { Fig. } & 3 . & \text { Apples from the same orchard sprayed. } & \ldots & \ldots & \ldots & 8\end{array}$

Fig. 4. Branches from sprayed and unsprayed apple trees. $\quad \ldots \quad 9$

Fig. 5. Roots attacked by the Root-knot Eelworm. $\quad \ldots \quad \ldots \quad$ I 8

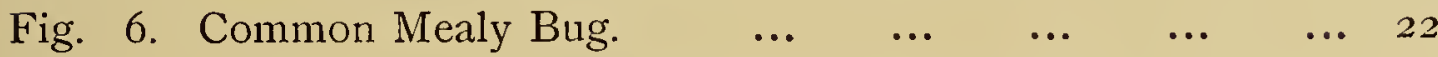

Fig. 7. Apple Shoots attacked by the Woolly Aphis. $\quad \ldots \quad$.. 25

$\begin{array}{llllllll}\text { Fig. } & 8 . & \text { The Apple Sucker }(P \text { sylla } \text { mali). } & \ldots & \ldots & \ldots & \ldots & 29\end{array}$

$\begin{array}{llllllll}\text { Fig. } & 9 . & \text { The Currant or Magpie Moth. } & \ldots & \ldots & \ldots & \ldots & 36\end{array}$

$\begin{array}{llllllll}\text { Fig. Io. The Winter Moth. } & \ldots & \ldots & \ldots & \ldots & \ldots & \ldots & 37\end{array}$

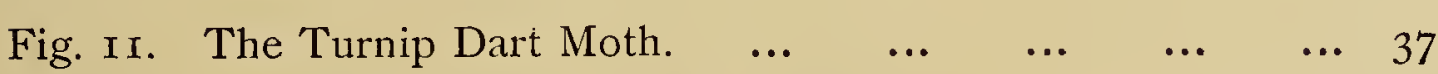

Fig. I2. The Great Yellow Underwing Moth. $\quad \ldots \quad \ldots \quad \ldots \quad 38$

Fig. I3. Tent of the Apple Ermine Moth. ... $\quad \ldots \quad \ldots \quad \ldots \quad 40$ 



\section{REPORT}

ON-THE

\section{Injurious Insects And other Animals \\ Observed in the Midiland Counties}

DURING I907.

"Our agricultural interests demand protection from the numerous enemies which thrcaten them, and the indifference with which farmers' requests have been listened to in the past is incompatible with that intelligence which should elevate his calling, and which is absolutely necessary to enable him to carry it on profitably."

"At present he is beset with obstacles on every hand, and none but the weil-informed are successful; for success in Agriculture and Horticulture, to-day, implies knowledge-scientific knowledge."-CharLes V. Riley.

[5th Ann. Missouri Rpt. on Noxious, Beneficial Insects, I873, p. 23.]

"It is the study of the principles underlying insect life and control which furnishes a field for research, but little tilled, and with unuch virgin soil. . . . There are abundant opportunities for research of the highest order in entomology, strictly econonic, and related to agriculture."

E. Dwight Sanderson.

[Proc. Igth Ann. Meeting Assoc. Econ. Entom., I907, p. 77.]

\section{INTRODUCTION.}

DURING the year January 3 Ist, I907, to January 3 Ist, I908, one thousand eight hundred and seventy-five inquiries have been dealt with. Of these, sixteen hundred and twenty-three were connected with agricultural and garden pests, twenty-six referred to household or commercial pests, and two hundred and twenty-six specimens were sent in for identification. 
Applications for information were dealt with from the Board of Agriculture and Fisheries, the Bureau of Entomology of the U.S. Department of Agriculture; the Land Agents' Society; the Midland Re-afforesting Association; the Warwickshire Agricultural Society; and the Agricultural and Educational Committees of various County Councils.

In all two thousand and thirty-five written replies have been sent out.

As compared with former years, for which details were kept, the figures are as follows:-

\begin{tabular}{|c|c|c|c|c|c|}
\hline I903 & $\ldots$ & $\ldots$ & $\ldots$ & I 89 & inquiries. \\
\hline I904 & ... & $\ldots$ & ... & 325 & $"$ \\
\hline 1905 & ... & ... & $\cdots$ & +79 & " \\
\hline 1906 & $\ldots$ & ... & $\ldots$ & I I 7 I & $"$ \\
\hline 1907 & ... & ... & $\ldots$ & I 875 & $"$ \\
\hline
\end{tabular}

My hearty thanlis are due to Messrs. H. Willoughby Ellis, F.E.S., A. H. Martineau, F.E.S., and Claude Morley, F.E.S., for various services rendered.

The year I907, proved, so far as animal pests were concerned, a great improvement upon its predecessor. This is partly accounted for by two facts, ri\%, the year was a very wet one, and also a considerable amount of careful winter spraying had been done in the winter of I906-07.

No particular pest has stood out conspicuously: In Worcestershire the larvic of the Wood Leopard Moth have done much harm to young fruit trees. A new pest to Gooseberries has been discorered, but fortunately, so far as I know, it is confined to one plantation. The Apple Sucker, the Winter Moth, and the Lackey Moth are still all too plentiful in all the Midland Counties.

Eelworms, Wireworms, the May Bug, and the larvae of the Turnip Dart Moth have proved very injurious to root crops.

The Felted Becel Coccus was found in Staffordshire. As I have pointed out in previous Reports, this pest is slowly but surely spreading throughout the country; and is likely ere long to prove very serious on landed estates where beech trees are in any number.

The Yellow Wood Wasp has been sent in from numerous correspondents and secms to have heen musually plentiful during 1907.

There is a decided increase of the Moolly Aplis. Some of the worst infestations I have erer seen have heen noted during the past year.

\section{INVESTIGATIONS.}

During the past year the work on Insecticides has heen continued, as also the experinesits upon the Lime and Sulphur treatment for 
the Black Currant Gall Mite, particulars of both of which will be found on pages 7 and io respectively.

The experiments made with a view to finding a remedy for Eelworms have proved most successful, these are set forth in detail on page I7.

\section{ORCHARD INSPECTION.}

Many orchards in the Midland Counties have been inspected and recommendations made thereon. Although this work has entailed considerable labour and time, I have good reason to know that it has been fully appreciated, and that growers have profited by the opportunity thus offered of discussing in the orchard the various pests and diseases, with which they had to contend.

\section{PUBLICATIONS.}

The following papers, etc., have been published :-

I. A New Gooseberry Pest (Eriopliyes grossulariae).

"Gardeners' Chronicle," p. I77, I907.

2. Some Insects Injurious to Barley and other grain when in Store. "Journ. Inst. of Brewing, I907," vol. xiii, pp. 242-265.

3. First Annual Report of the Honorary Consulting Zoologist. "Journ. Land Agents' Soc., I907," vol. vi, 248-259, 3 figs.

4. Report on the Injurious Insects and other Animals observed in the Midland Counties during 1906.

Birmingham : Cornish Bros., Ltd.

5. On the Eradication of the Black-Currant Gall-Mite. (Erioplyes ribis, Nalepa.

"U.S. Dept. Agric., Bur. of Entom., Bull. No. 67, I907," pp. I I9-I23.

6. The Application of Economic Biology to Agriculture.

"Journ. Econ. Biology, I907," vol. 2, pp. 96-го6.

\section{LECTURES AND ADDRESSES.}

1907.

I. Jan 23. Insects Useful and Injurious.

Bontuville Village Council.

2. Jan. 28. The Protection of Injurious Wild Birds.

Birmingham and Midland Connties Gardeners' Association.

3. Feb. I3. Animal Pests of the Garden.

The University.

4. Feb. I5. The Principles and Practice of Plant Spraying.

Eveshan Frnit Pests Connniltee.

5. Feb. 20. The Red "Spider" and other Mites.

The University. 
6. Feb. 27. Garden Friends and Foes.

Royal Socicly of Arlists, Birmingham.

7. Feb. 27. Earwigs and Greenflies.

The Uniarisily.

8. Mar. I. British Gall-Mites.

lesey Club, Sullon Coldficld.

9. Mar. 7. Scale Insects and Ground Caterpillars.

The Uniarersill:

Io. Mar. I3. Leaf Mining Insects and Saw-flies.

The Unirio'sils.

I M. Mar. 15. The Spraying of Fruit Trees.

Eassham Fruil Pest Commillec.

12. Mar. 23. Some Parasites of Sheep and Cattle : Their Prevention and Cure.

Iraraickshire Chamber of Asricullure.

13. July t. On the Cecidomyidac or Gall-Midges.

5th Meclins of the Assoc. Economic Biolosists held al llic Imperial Inslitule, London.

I4. Aug. 2. On the Rise and Recognition of Economic Biology:

Brilish Associalion, Leicester Meclins.

15. Aug. 29. Useful and Injurious Insects.

II 'oolhope Naluralists' Ficld Club.

I6. Oct. Io. Insects Injurious to Farm and Garden Crops.

Sidderminster Horlicullural Socicty.

17. Oct. 17. The Application of Economic Biology to Agriculture.

bristol Liniarersily College.

I8. Nov. II. The Moolly Aphis and other Greenflies.

Birminglam .Microscopisls' Unim.

19. Dec. 6. Some Common Garden Pests and How to Treat Them.

Sullon Coldficld and Fom Oaks Ladies' Gurdenins c $l i l b$.

\section{INJURIOUS FUNGI.}

Althomgh primarily concerned with Animal pests and Animal Discases, the Department hats received numerous incpuries relating to injurious fungi. During I 907 , there has heen a latge increase in the number of such inguiries, and it maty therefore be of interest to schedule the more important discases, which will be treated of later.

\section{Fruit Trees.}

Brown Rot (Silerolinia frmetisism, Pers.)

Apple Scab or " Black Spot" (Fusicledimm domelriticum, Fekl.).

Pear Scab (Fusiclalumm firimum, lib.). 
Canker (Nectria ditissima (Tal.)).

Coral Spot (Nectria cinnabarina, Fr.).

Powdery Mildew of the Apple (Podosphaera lencotricha, E. \& E.).

Cherry Leaf-Scorch (Gnomonia erythrostoma, Auersw.).

American Gooseberry Mildew (Sphaerotheca mors-uvae (Schw.), Berk.).

Currant Leaf Spot (Seploria ribis, Desm.).

Peach Freckle (Cladosporinm carpoplitlum (Thüm.)).

Peach Leaf-Curl (Exoascus dcformans, Fckl.).

\section{Tomato, etc.}

Sleepy Disease of Tomato (Fusarium lycopersici (Sacc.)).

Cucumber Leaf Blotch (Cercospora meloris (Cookej).

Finger and Toe (Plasmodiopliora brassicae (Wor.)).

Heart Rot of Mangolds (Sphaerella tabifica (P. \& D.)).

Potato Disease (Phytophora infestans (De Barry)).

Potato Scab (Oospora scabies (Fisch.)).

Yellow Wart Disease (Chrysophlyctis endobiotica, Sch.).

\section{Forest Trees.}

Saddle-Back Fungus (Polyportus squamosus, Huds.).

Paving Block Fungus (Lentinus lepidens, Fr.).

Horse Chestnut Stereum (Stereum purpureum, Fries.).

Honey Fungus of Pine (Agaricus melleus, L.).

\section{Miscellaneous.}

Mint Rust (Puccinia mentlace (Pers.)).

Dry Rot (Merulius lacrymans, Fr.).

White Mould in Violets (Ramularia lactea, Desm.)). 


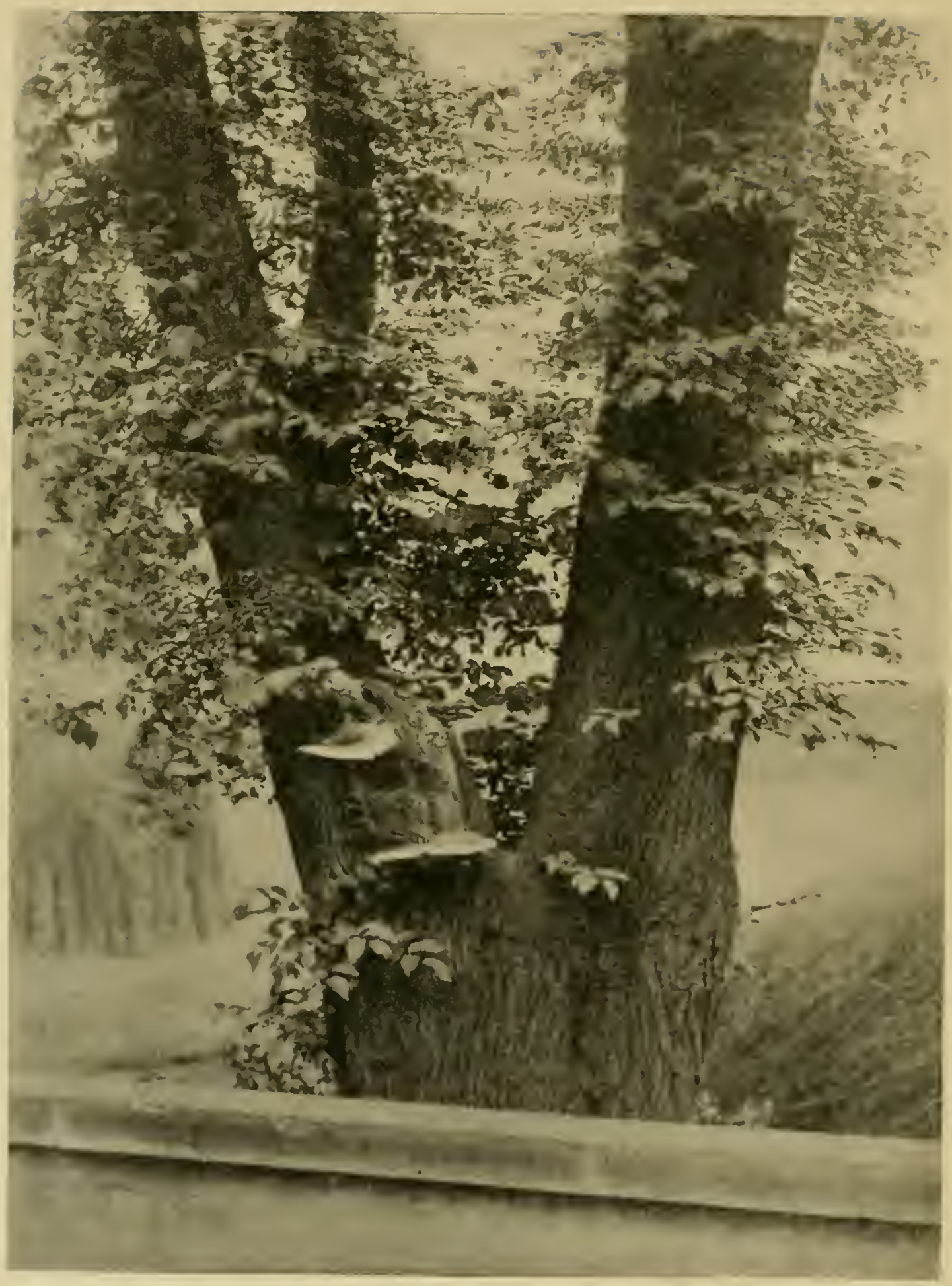

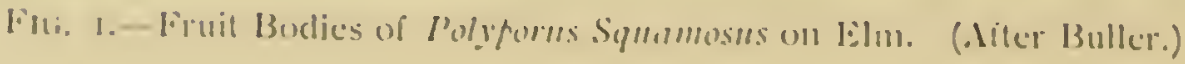




\section{REPORT ON EXPERIMENTS WITH INSECTICIDES AND FUNGICIDES.}

Since the publication of my last Report much work has been carried out on insecticides and fungicides, both in the laboratory and in the orchard.

Experiments with the lime and salt fluid, for killing the eggs of the Apple Sucker and Mussel Scale, have proved once and for all, so far as the writer is concerned, the uselessness of this sprayfluid.

The mixture used was as follows :-

$\begin{array}{lllll}\text { Best White Lime } & \ldots & \ldots & \ldots & \text { I68 lbs. } \\ \text { Agricultural Salt } & \ldots & \ldots & \ldots & \text { 30 lbs. } \\ \text { Water } \quad \ldots & \ldots & \ldots & \ldots & \text { roo gallons. }\end{array}$

Very careful observations have been made upon the material in the laboratory and also upon the trees in the open. In the laboratory the highest percentage of eggs of the Apple Sucker destroyed was 42 per cent., and of Mussel Scale, 38 per cent.

In the open the percentage must have been considerably less.

The results obtained with the VI and V2 Fluids continue most satisfactory. It is not too much to state that, to use the words of a grower, "they are transforming the orchards of this country."

Very important results have been obtained with a mixture of the VI and V2 Fluids and potassium sulphide, as a cure for the American Gooseberry Mildew. The potassium sulphide has been combined with both for the purposes of winter and summer spraying, the former being known as the VI K Fluid, and the latter as the V2 K Fluid.

I am hoping to have an extensive series of experiments made with these two fluids upon a large number of fungus diseases.

Among other matters that have received attention are the better preparation of Bordeaux mixture, and the preparation of an Arsenate of Lead paste or fluid at a considerably less cost than this can at present be obtained, and some experiments designed to provide a more effective sprayfluid for hops.

The action of all of these specifics has been carefully noted and a full report will be published at a later date. 

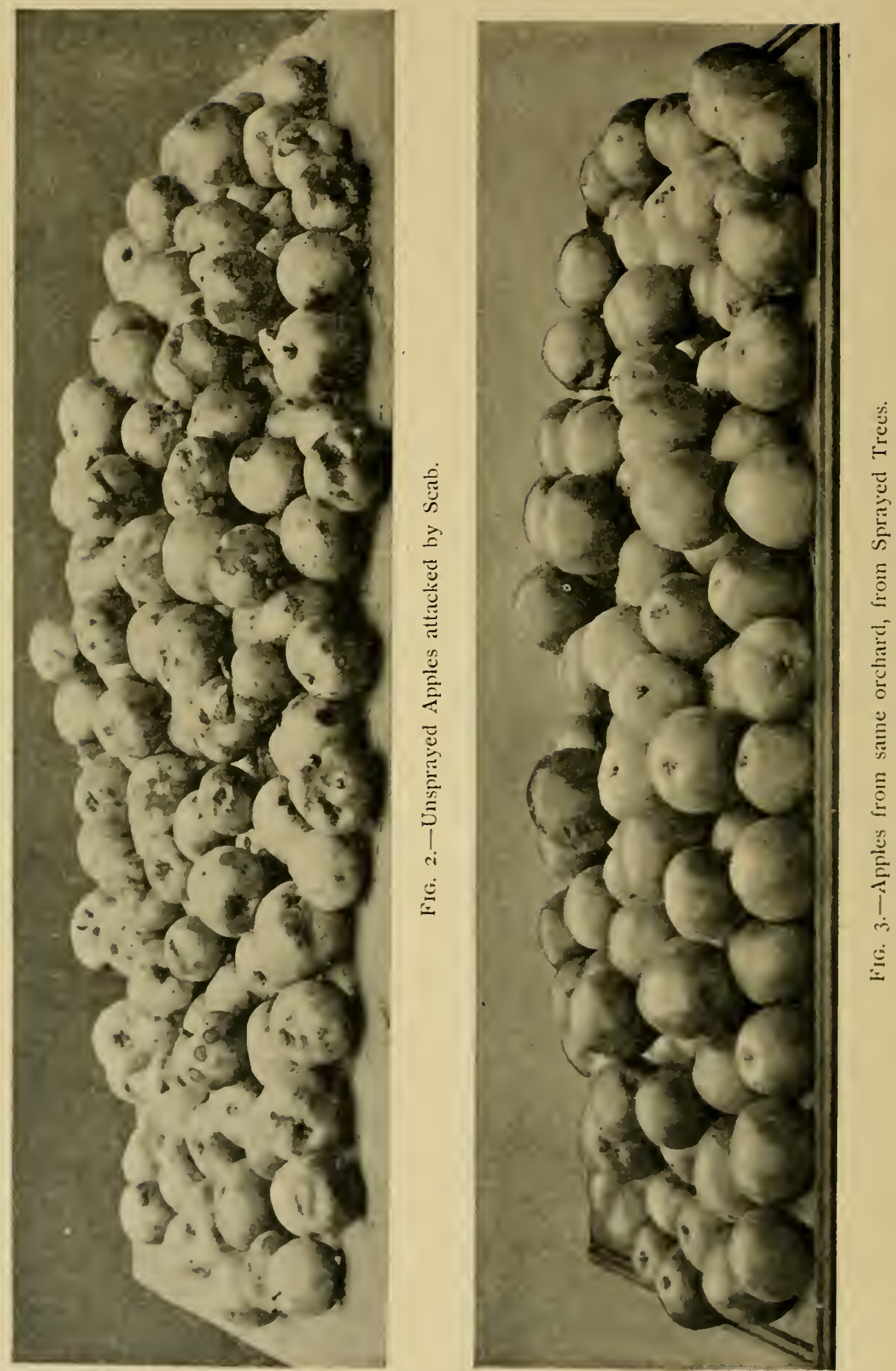


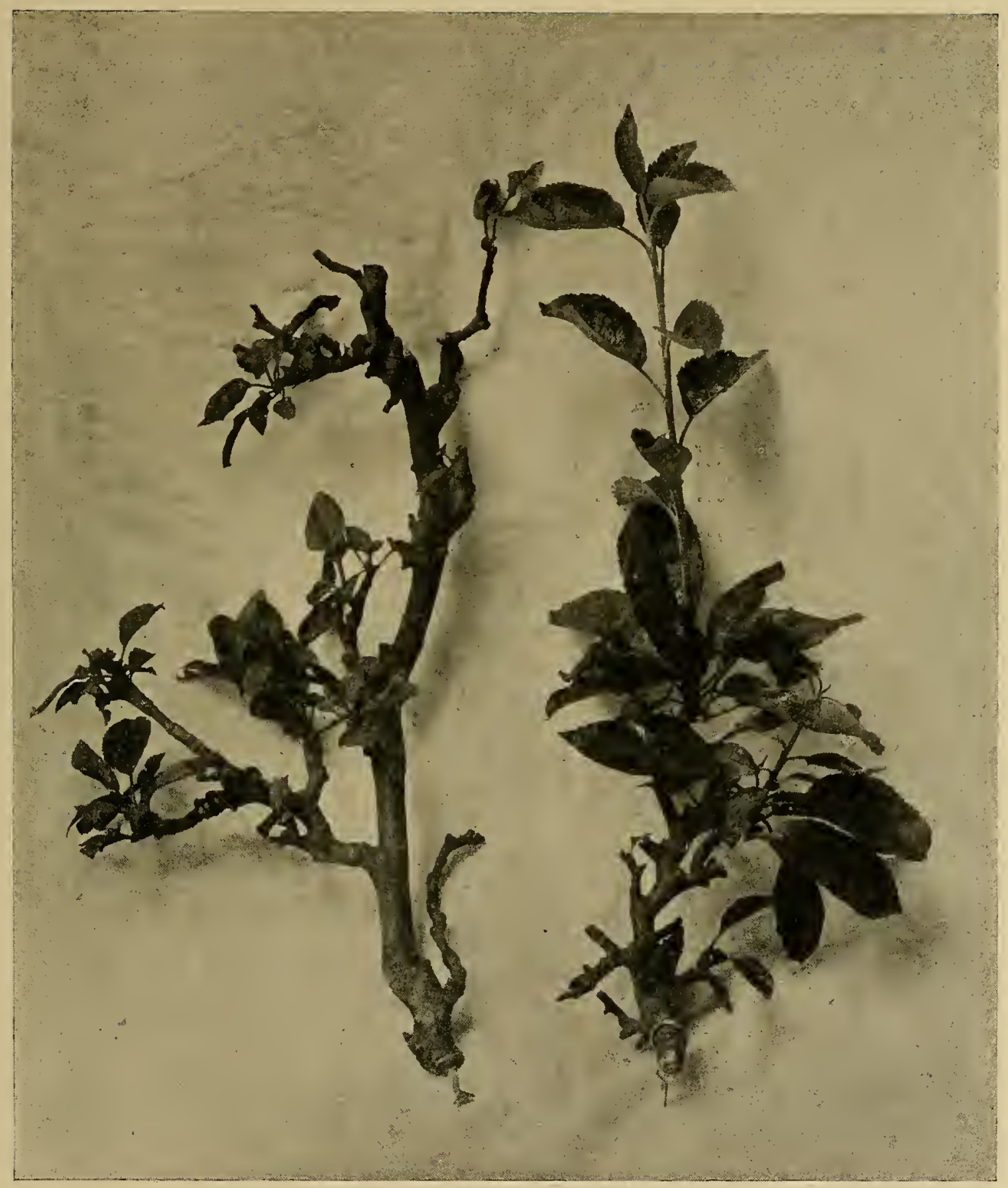

FIG. 4.-Branches from sprayed and unsprayed Apple Trees. Note the new wood and large healthy leaves on the sprayed branch on the right. 


\section{REPORT ON EXPERIMENTS \\ WITH THE BLACK-CURRANT GALL-MITE.}

Erioplyes ribis (Nalepa).

The experiments on the Blacl-Currant Gall-Mite, Eriophyes ribis (Nalepa), were commenced by me in the early part of I899. After a thorough investigation of the life history and habits of the mite ${ }^{(x)}$ attention was devoted to provicling a remedy:

Various experiments were made with different arsenical fluids, bruised hellebore, lime, sulphur and lime, etc., and whilst many considerably reduced the numbers of mites, none were found to be of any practical value.

In I90I, some bushes badly infested with the mite were treated twice a week during the migration season with a sprayfluid consisting of :-

$$
\begin{array}{lllllc}
\text { Sulphur } & \ldots & \ldots & \ldots & \ldots & 2 \text { lbs. } \\
\text { Soft Soap } & \ldots & \ldots & \ldots & \ldots & 25 \text { lbs. } \\
\text { Water } & \ldots & \ldots & \ldots & \ldots & 50 \text { gallons. }
\end{array}
$$

Made as follows:-The sulphur was mixed with water to a gruel ; the soft soap was mixed with 5 gallons of boiling water, and then the two mixtures were added together and well mixed, water being added to make 50 gallons. The results obtained from the use of this mixture were very encouraging, but it was soon evident that it could not be applied by the fruit-grower at a cost which would repay him for the extra labour involved. The two main objections were, firstly, the large number of applications which were given in my experiments, and, secondly, the large quantity of soap used. But these experiments very clearly indicated that the mite could be destroyed to a large extent by the use of sulphur, and it but remained to be demonstrated in what form and proportions it could best be applied, and whether the number of applications could be reduced.

In 1905 a further series of experiments were commenced on very badly infected Black Naples, Baldwins, and Boskoop Giants. These were as follows:-

Three rows of bushes were dusted with equal parts of ground unslaked lime and flowers of sulphur. Three rows were sprayed with a mixture consisting of I lh. lime, $1 \mathrm{lh}$. sulphur, and 20 gallons of water ; whilst a single row was sprayed with a mixture consisting of $\mathrm{I} l \mathrm{~b}$. sulphur, I lb. soft soap, and 20 gallons of water.

In the dusting operations one row was clusted once, one twice, and one threc times.

(1) Report on licomomic \%onlngy, Sn. \&, sxal 
As a result of these experiments it was clearly shown that the mite could be kept in check by the application of lime and sulphur, and I part of the former, and 2 parts of the latter were recommended to some hundreds of growers.

In the spring of 1907 a still further series of experiments was tried, the quantities of lime and sulphur being :-

Ist Dressing.-I part of ground unslaked lime, and 4 parts of sulphur.

2nd Dressing (a fortnight later).- I part of lime and 8 parts of sulphur.

$3^{r}$ d and 4 th Dressing (at intervals of a fortnight).-Sulphur only.

This has been, if anything, more successful than the old formula and has the advantage of not burning the leaves or blossoms.

In his Report for 1906-7, Mr. F. V. Theobald states in reference to my suggested treatment with lime and sulphur, "Migration of the mites is spread over too wide a period to ever hope that this treatment will do any permanent good. But it is encouraging to know that some success has been obtained."

In order that fruit-growers may judge for themselves, I publish the following extracts, from some hundreds of similar letters, received from fruit-growers in all parts of the United Kingdom.

I._." I have dressed about 5,000 Black Currant bushes, 4,000 three times and r,ooo twice, and they are all free from the mite at present."

2.- "Three years ago there were 40 Black Currant bushes of various sizes, all more or less infested with the mite. On the advice of a local gardener I cut down 7 , leaving 33, off which we gathered 8 to Io lbs. of poor currants. A year ago we gathered about the same quantity. During the early spring I saw your remedy. This April, between the Ist and 2oth, I dusted the bushes with the sulphur and lime as you directed, and the result was 4 stone of really good fruit, and to all appearance healthy trees."

3.- "I am pleased to tell you my bushes are practically cleared. I dressed 3 acres of old bushes, very bad, and on inspecting them this morning only found here and there a twig with some buds showing. 9/1oths are quite clear, these I dressed three times. On another I2 acres of younger plants I cannot find any there. Some others I only dressed twice and they are free."

4.--"I applied the treatment you recommended to a large number of Black Currant bushes with unqualified success. The crop realised over $f_{3} 3^{\circ}$ when sent to Covent Garden."

5.- "In the spring I cut out from a local paper a copy of your letter re the Black-Currant Gall-Mite. The remedy has been most successful." 
6.- "The treatment for eradicating Black Currant Mite recommended by you has been rery successiul, and I am pleased with the results on six acres."

7.- "I treated the bushes this spring and had a crop of fruit, the first for + years. The bushes are almost cutirely cleared, and I am proposing to repeat the process next year to make a sure clearance. I am pleased I did not resort to the heroic remedy of stubbing up the bushes, as others in this neighbourhood lave clone, and as I was advised to do.

"With many thanks for linding us so good a remedy."

8.- "I am enclosing shoots of Black Currants which have been dusted three times-once during the last week of March, the third week in April, and the first week in May. I followed out your directions as accurately as possible, and as far as I can see it is an effectual remedy; but I wish you to examine the buds microscopically, as I feel it necessary to be quile sure of the actual results of all experiments."

Mr. P. Blair Oliphant, the Managing Director of the Ardblatir Blairgowrie Fruitgrowers, Ltd., has very kindly furnished the following report :-

\section{Gexeral, Remarks on Previols History of Disease in these Plantations.}

"The 'big bud' did not make its appearance until the bushes had been planted three or four years. It then began in the low ground of the West plantation and spread rapidly to the surrounding rows. Badly infected hushes were cut out and burned, and on bushes which were only slightly infected, the infected shoots were pruned away.

The experiment was tried of cutting down infected bushes to the ground, and allowing them to come away from the root. But, I think I may say, that in every single case where this was done the young shoots developed a clouble share of the disease. This would seem to indicate that the mite comes either from the root of the bush or from the soil itself. It was noticeable, on the other hand, that the young plants which were substituted for the bushes, which were uprooted, did not develop the discase so readily ats those that were cut down.

Another peculiarity which I have noticed is, that some bushes be:ar nettle-like leaves, and present a gencrally unlealthy appeamance. There maty be a hig flomish of blossom on these: but it imvariably withers away and comes to nothing. I attribute this to the bushes being wealiened by the discitse, and heing more susceptihle to frost and rime.

In the year loot the IVest plantation bore a heary crop of fiut, in spite of the fact that 10 per cent. of the hushes fated as described above. The crop amomited to oret 3 toms. 
In 1905 this plantation was well manured, and in May it looked as though it would repeat the crop of the previous year, but a night or two of frost early in June carried it nearly all away, only 29 cwts. being got from it.

In the spring of this year (1905), no less than 300 bushes were uprooted and burnt from the two plantations, the ground was given a dose of ground lime, and broad beans were sown between the bushes where they were badly infected.

In 1906 the big bud appeared diminished. Only one. hundred bushes were uprooted, and the remainder were carefully hand-picked twice over for big bud. The crop was a very poor one. The West plantation establishing a record of failure by producing only i 5 cwts. of fruit, and very little young wood was made.

In I907-at the time of writing-the disease is far worse than it has ever been before. I was considering whether it would not be better to uproot the whole of the West plantation, when the sulphur and lime treatment was brought to my notice.

\section{Report on Black Currant Plantations.}

\section{Treathent for "Big Bud" in Black Currant Plantations.}

\section{$\left.\begin{array}{l}\text { East Plantation, } 1 \frac{1}{2} \text { acres. } \\ \text { West Plantation, } 2 \text { acres. }\end{array}\right\}$ about $\left\{\begin{array}{l}2,500 \text { plants. } \\ 3,500 \text { plants. }\end{array}\right.$}

The East plantation has been planted four years. The bushes are at full bearing, and, for the most part, well grown, but the centre portion is badly affected with "Big Bud," and the outer rows to a lesser degree.

The West plantation, planted about eight years, is very badly affected over the whole of the low-lying portion, and very slightly on the brae, where the bushes are very well grown, and have proved consistently good croppers.

East Plantation.-1st application, April 8th and 9th, 1907. All infected bushes clusted with 2 parts flowers of sulphur to I part of ground lime. Coronette Knapsack Sprayer used.

Weather conditions. 8th.-Bushes wet with rain in morning, fine afterwards. Dusting continued until 3 p.m., when bushes dried.

9th.-Wet night. Showery during day. Dusting continued until afternoon when wind dried bushes.

West Plantation.--Ist application, April 9th and Ioth, I907. Infected bushes dusted as in East plantation.

Weather on Ioth, showery, with East wind all day. Dusting carried on until 5 p.m.

At date of writing (Ioth April,) none of the swollen buds appear to have burst. Most of the other buds are putting out leaves. 
Easl Planlation.-2nd application, April 23rd, r907. Infected bushes dusted with $2 \frac{1}{2}$ parts flowers of sulphum to I part of lime ('Two Coronette Sprayers in use.)

II calher condilions. Still morning; bushes wet with dew; but subsequently dried. Dusting continued all day and plantations finished, also a few rows of West plantation.

Powder from Ist application still adhering to some bushes.

If est Plantalion.-April 23rd, 1907. A few rows dusted in afternoon. Bushes rather dry.

April 25th, 26th, 27th. Remainder of infected bushes in plantation dusted in mornings from 6.30 to ro a.m.

IIeather condilions. Dry and breezy. Dew soon dried on bushes, and dusting was discontinued early.

At the date of writing (29th April,) very little powder is visible on bushes. There was some rain on the erening of the 26 th and showers since, and a fair amount of wind.

Most of the swollen buds appear to have cracked or burst. When examincd under microscope on the $25^{\text {th }}$, bucls were seen to contain mites, some alive and some apparently dead.

Leaves are coming on slowly, and a certain amount of fruit blossom. Season is backward owing to cold winds and night frosts.

Easl Planlation.-3rd application, May $9^{\text {th. }}$ Infected bushes dusted with 3 parts flowers of sulphur to I part lime.

II caller conditions. Fine morning, bushes wet with dew. Dusting continued until I2 o'clock, when plantation was funished. Breeze sprang up in afternoon and some showers.

Wesl Planlation.-May Ioth. Infected bushes clusted as in East Plantation.

Wealher condilions. Bushes wet with dew, and slight showers. Plantation funished. Powder adhering fairly well to bushes: hut not so well as when a greater proportion of lime was used.

Total weight of Sulphur used for 3 applications $3 !$ cwts.

$$
\text { Lime " " " } \quad \text { I.] cirts. }
$$

Ioth Mity. Bushes now in full hloom. Mest Plintation does not promise well.

REPORT ON 3rd SEPTEMBER, IgO7.

The Crop from both plantations was heavied than in 1yo6. The Mest Plantation yickled 25 cwts. and the Eist 29 . A good deal of the frut wits of poor yuality, and the leaves withered from mamy of the bushes before the crop was gathered, young huds are hegiming to show: hut it is too cirly to sily whether the sall mite is present in them or not. As a rule, I have noticed that the swollen buds begin to show in October or Norember, hut no iclea of the extent of the discatse cam be formed mutil the spring." 
The following opinions are extracted from the Fournal of Horticulture, of November 7 th, I4th, and 28 th, 1907 :-

"In the early summer I wrote to you about the lime and sulphur remedy for the Black Currant mite . . and expressed a wish that those who tried it would record the results of their experiments in our Foumal this autumn. As this is a serious pest, I trust others besides myself will respond. . . Although we have some very bad bushes here, the majority are only partly affected, and these are nearly all dusted over with the mixture (two parts sulphur, one part lime) once during the last week of March and the third week in April.

After the last application I noticed many of the leaves dropped (these were not the youngest), and some of the flowers were burnt. This was rather discouraging, as there was promise of a splendid crop of fruit, and I did not want to lose it. I therefore only treated a certain number of bushes with the last application in May, the mixture being altered in its proportions to three parts of sulphur and one part lime. Even this seemed too strong, for many more leaves fell off and the fruit bunches were spoilt, which gave the bushes a very sickly appearance. All the bushes have been examined during the last week, and I find that those which received two dustings only are very little better than those which have not been done, but those that received a third dressing are quite free from mite as far as can be seen by the naked eye, and have quite recovered from the check which they received. From these results it would seem that only the third application were necessary, but I should say that it is safer to give at least two, as a late season may make a difference to the exodus of the mites from the old buds.

$$
\text { L.F.D." }
$$

"After reading 'L.F.D.'s' letter in last week's Fournal on the results of his sulphur and lime treatment for the eradication of the above-named pest, I went and examined our bushes here, which were similarly treated, and I am exceedingly pleased to say, I could not detect any sign of the mite. Whether there will be any development later I am not able to say; but usually at this season of the year it is only too easily seen. Unlike your correspondent, I found no injury to foliage, flower, or fruit after the third treatment, although the currants were in full bloom at the time. The particulars and the prescribed conditions which appeared in the garden papers I could not, at the time, exactly carry out-(I part unslaked lime, ground fine, to 2 of sulphur, was recommended). I had to use air-slaked lime, instead of the quick, to 2 of sulphur. This was applied first, at the end of March ; second, middle of April ; third and last, the first week in May. My immunity from burning I attribute to using air-slaked lime with the sulphur. Our powder was applied with bellows.- 
"Wanderer," replying to the above states, "It is gratifying to note in the article of 'L.F.D.,' page +39 , that Mr. Collinge's remedy for the Black Currant mite is proving effectual. Accorcling to 'L.F.D.' the main point is never to miss giving the application in May. The earlier dustings in his case do not seem to have done very much good. It should, however, be borne in mind that the season last year was a peculiar one, and it is quite possible that the migrating season of the mite was in consequence delayed.

Mr. J. Easter also records his satisfaction at the results obtained by the use of the lime and sulphur remedy, notwithstanding the fact that the lime used in his case had been slaked. If air-slaked lime should prove as effectual as ground lime, it will undoubtedly prove an advantage, because of the lessened danger of burning the foliage. At any rate, growers now seem to have a reliable weapon in their hands. If they fail to use it, they have themselves only to blame."

Sumari :-To any unprejudiced mind $I$ think it will at once be clear that the lime and sulphur treatment is proving effective.

In the earlier experiments it is now certain that too much lime was used and this resulted in damage to the leares and blossoms.

Various correspondents have assured me that they have obtained excellent results with the use of air-slaked lime.

In conclusion, I should like to express my personal thanks to the many hundreds of growers who have experimented with the lime and sulphur treatment, for I feel it is largely due to them that it has been shown that we can control, if not exterminate, a pest which at one time seriously threatened the cultivation of Black Currants in this country. 


\section{REPORT ON EXPERIMENTS WITH EELWORMS.}

\section{THE FUMIGATION OF THE SOIL.}

In the winter of 1905 I commenced a series of experiments with a view to finding something that would effectually rid the soil of Eelworms. After various substances were tried the experiments gradually led up to reconsidering the whole subject of the fumigation of the soil, and a long and elaborate series of experiments were planned and carried out.

During the past few years very rapid strides have been made in this and other countries, in the methods for combating Insect and other animal pests which are injurious to various plants.

Thus, by spraying and fumigation, the farmer, fruit grower, and horticulturist are now able to deal with a large number of pests and to control the same, which means that better crops are obtained and of an increased value.

But there are certain pests which it is impossible to control by spraying or by the existing methods of fumigation.

The two fumigants at present in general use are carbon bisulphide and hydrocyanic acid gas, both highly dangerous substances except in the hands of skilled people. Further, whilst both of these substances are admirable for fumigating plants under glass, etc., they are scarcely practicable when one has to take into consideration a great acreage of land.

As is well-known, the caterpillars or grubs of many insects spend that period of their life in the soil, feeding upon the roots of various plants, that many others spend the pupal or chrysalis stage there, whilst a few remain underground throughout life.

Amongst these insects we may mention:

Springtails; the Pea and Corn Thrips; the Mole Cricket; the Cockchafer Beetle ; the Green Rose-chafer ; the May Bug; the Asparagus Beetle; the Mustard Beetle; the Nut, Pea, Vine, Turnip Gall and many other Weevils or Snout Beetles; the Hop Flea Beetle; the Turnip Flea Beetle; the Skipjacks (Wireworms); and the Pigmy Mangold Beetle.

Also the Turnip Dart Moth ; the Yellow Underwing Moth; the Antler Moth; the Ghost or Otter Moth ; the Small Swift Moth; the Hart and Dart Moth; the Pea Moth ; the Cabbage Moth ; the Currant. or Magpie Moth; and the Common Rustic Moth.

The Woolly Aphis (Root Form); the Fruit-Tree Root Louse; Phylloxera; the Root Mealy Bug.

The Onion Fly; the Mangel Fly; the Fever Fly; the Carrot Fly; the Celery Fly ; Crane Flies (Leather Jackets); the Pear Midge ; the Pea Midge; the Wheat Midge. 


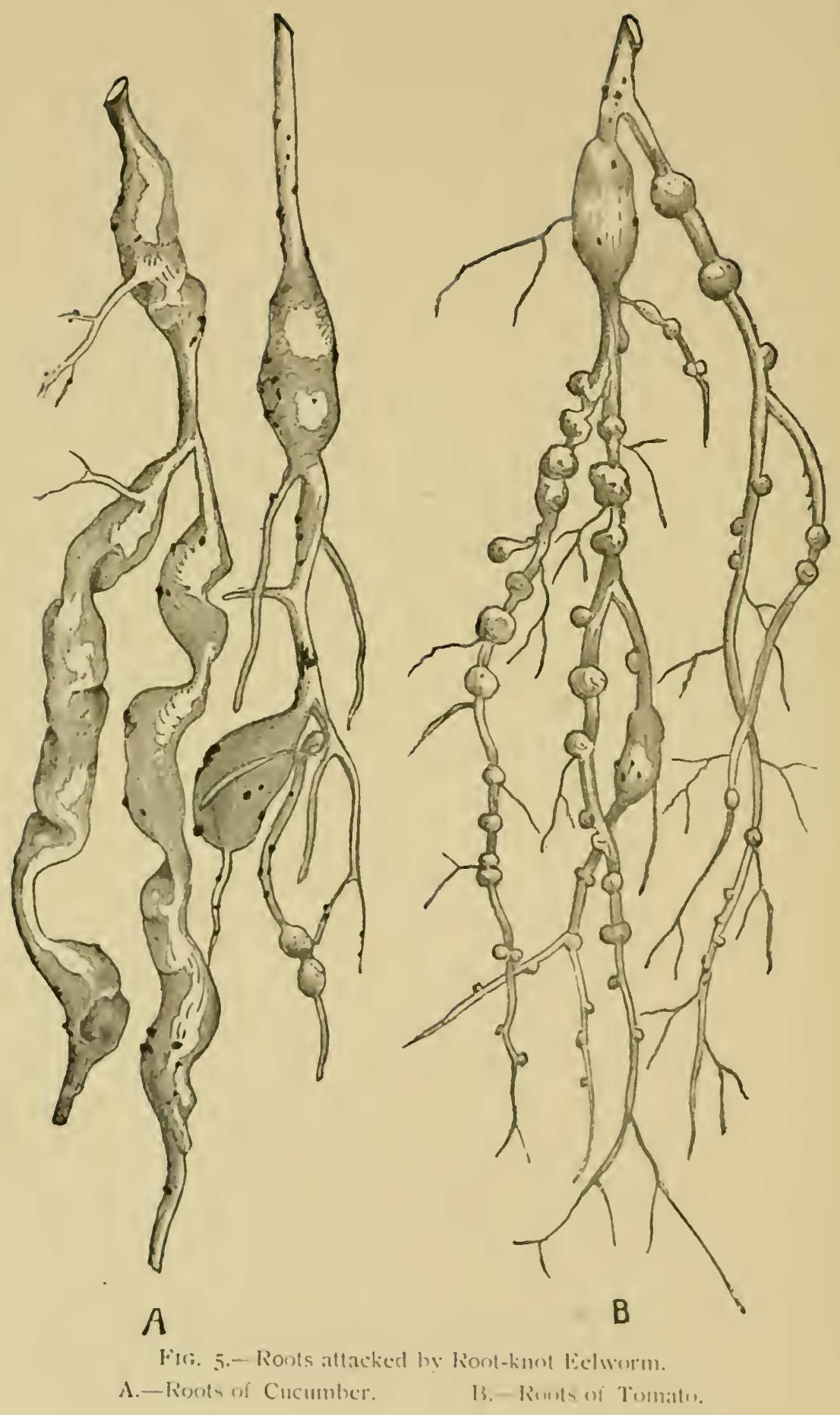


The Pear Slug; the Gooseberry Sawfly; the Turnip Sawfly; etc., also such pests as Eelworms; Woodlice; Millipedes; Ants ; etc.

These pests singly, or in conjunction, are levying a toll upon our crops of from 25 to 75 per cent.

The question naturally arises "How shall we proceed to get rid of these pests?" and our answer is Fumigate the Soil.

This can now be done with the minimum outlay of labour and expense. After a long and elaborate series of experiments I have obtained a fumigant which will effectually rid the soil of one and all of the above mentioned pests; and to this material I have given the name "Apterite." .

Apterite is quite distinct from, and a great advance upon, any of the so-called soil insecticides, for the active principle works upwards and downwards.

It has been very truly said that by its application a revolution in Agriculture will be brought about.

In my opinion it is the only material that has yet been found that will economically rid the soil of these insidious pests known as Eelworms; and, if for no other reason, it will be welcomed by all agriculturists suffering from such.

My first experiment was made in the autumn of 1906 upon soil in which daffodils and hyacinths were being grown, and which was known to be badly infested with Eelworms.

In the spring of 1907 I had the opportunity of treating the soil in a large tomato house, which was infested with the Root-Knot Eelworm.

Various plots were also treated on which clover, vegetable marrows, etc., were being grown. clover.

Finally it was tried on a much larger scale, viz., on oats and

The results in each case were practically identical ; but perhaps most strikingly shown on the tomatoes, where there was a complete absence of Root-Knots; and a fine, healthy crop was obtained. 


\section{REPORT UPON INSECT PARASITES OF INSECTS.}

In this fascinating branch of Economic Biolog! much useful work has been accomplished.

Two species of Ichnemons (both probably new to science) have been bred from the Plum Aphis (Afhis promi. Réammur) and valuahle information has heen collected as to their economic importance.

An attempt was made to breed and distribute examples of Aphidins silenes, Marshall, a small Icluemon which parasitises the Peal Aphis (Siphonoplrora pisi, Kalt.), with most beneticial results.

Various species of Hovering Flies (Syrphidac) and Ladybird Beetles (Cocindlidac) have been bred and distributed.

There is undoubtedly a very important field for work on these lines in the fruit-growing districts of the Midlands, and whilst I do not for one moment think that we are ever likely to reap the results from native parasites as accrue from the introduction of foreign species, yet they undoubtedly exercise a control upon the numbers of this or that particular pest, which is to the advantage of the fruit-grower.

\section{THE GOOSEBERRY GALL-MITE. \\ Eriophyes grossulariac, Cllge.}

E:rly in the year an Eresham correspondent forwarded me some Gooseberry cuttings on which all the present year's buds appeared dry and shrivelled. All the onter leaves were quite dead, and in some cases the bark was peeling off in long shreds.

Careful examination for a fungus or some boring insect laria was unrewarded by any success, so as a final resort I teased a bud, just as one would do to find the Black Currant Gall-Mite, and I was rery much surpriser to find a mite of the genus Erioplines.

Further examination showed that practically all the remaining buds were infected.

Growers noticing buds which appear dead or chying up on the new wood should immediately cut it awa, and destroy by burning.

\section{THE BULB MITE.}

Rhizoslypluns colimopus, li. \& R.

A somewhat serious attacli of this mite wats reported by at Wirwickshire correspondent; tulips and hyacinths were the bulbs itticlied.

The life-history is only imperfectly understood. The engs give rise to six-legged larvac; which, later on develop into mymphs possessing legs. These, after undergening a comple of moults, hecome the sexually mature adults.

What is known as a hypopial stage maly oceur ; and it is in this stage that the species is spreate. The hypopus possesses on its under 
surface fourteen minute suckers, by means of which it is capable of attaching itself to other animals, and thus being carried away, and setting up fresh areas of infection.

\section{Preventive and Remedial Measures.}

All imported bulbs should be fumigated with bisulphide of carbon (see page $5^{6}$ ).

Once the bulbs have become infected remedial measures are of little avail; as the mites get between the leaf scales, and sometimes into the interior of the bulbs, where they lay their eggs. It is really the better plan to burn all infested bulbs, and to treat the soil with bisulphide of carbon.

Experiments were made on the bulbs by soaking and spraying them with various fluids, such as paraffin and turpentine emulsions, sulphide of potassium, etc., but none gave satisfactory results. No doubt many of the mites were killed, but sufficient numbers remained alive to complete the destruction of the bulb.

\section{THE HARVEST BUG.}

Leptus antumnualis, Shaw.

Writing from Bewdley in August last a correspondent states that during the whole of August, and part of July and September, this mite takes half the pleasure out of the country in neighbourhoods where it occurs.

The irritation set up on human beings when attacked by this tiny acarine is very painful. Fortunately, however, the so-called Harvest Bug is not a mature mite, but only a larval form, so that it does not breed on human beings. In all probability it is the young of a mite known as Trombidinm holosericelmm, as first asserted by Megnin in 1876 .

This species is well-known, and although very plentiful on wild and other grasses, it does not seem to do any damage to plant life. In its larval stage, however, it attacks man and most domesticated animals.

\section{THE PEA AND BEAN THRIPS.}

Thrips pisizora, Westwood.

A Warwickshire correspondent forwarded a number of developing pods of the garden pea, covered with little yellow thrips which are referred to this species.

As I have treated of the life-history of this pest so recently as in my Third Report, ${ }^{(\mathrm{r})}$ it is only necessary to repeat the preventive and remedial measures.

Wherever an attack of these insects has been experienced, the haulm and old stocks should be burnt. Neither peas or beans should be grown on or near the same ground the following year.

(I) Rpt. on 1nj. 1nsects, etc., for I905. 1906, p. I2. 
Liming and deep ploughing have also been recommended; and the removal of all rough herbage which affords a winter shelter.

\section{THE BROWN SCALE.}

Lccanium hemisthericum, Targ.-Toz\%.

On various plants this scale has been received from many correspondents during 1907. On a species of palm it was particularly prevalent; as also on Aspidium sp.

It is a very prolific species and often does serious damage to plants under glass. Fortmately it is sufficiently large to attract notice.

In the above-mentioned case, where it was found on palms, it was eradicated by the use of a quarter of a pound of soft soap mixed with a gallon and a half of boiling water, and a gill of paraffin. In other cases I lave used the VI Fluid, diluted I part to $\mathbf{r}_{5}$ o parts of water.

\section{THE BROWN CURRANT SCALE.}

Lecanimm persicac (Geoff.) var. coryli (Linn.).

Specimens of this Scale have been examined on Gooseberry plants, and both Black and Red Currants.

The Gooseberry twigs, which were forwarded by a Worcestershire correspondent, were very badly attacked. The bushes had been neglected for some time past and only the diminished crop of fruit served to claw the grower's attention to the fact that something was wrong.

In December the bushes were sprayed with the Vi Fluid, and already the stems are assuming a clean and healthy appeanance, free from the pest.

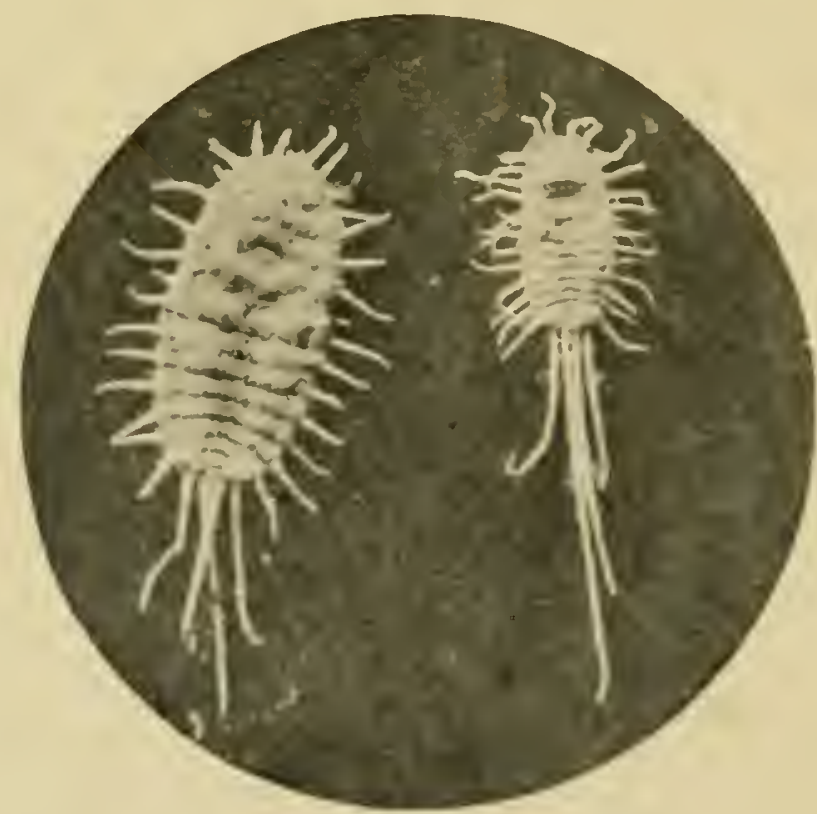

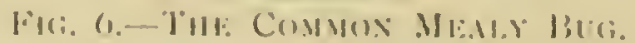

Two femalen in diflecent stigses of developument.

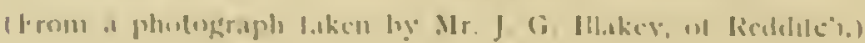




\section{MEALY BUGS.}

Dactylopius citri (Risso), and longispinns (Targ.-Tozz.).

Both of these Scales have been abundant and most destructive.

The first mentioned species was observed in great numbers by the writer, in a conservatory, on some rotten woodwork, indeed, far more plentiful in this particular spot than on the various plants it infected; or than ever I remember seeing it before.

Under glass, spraying with the V2 Fluid was found to be effective.

\section{THE FELTED BEECH COCCUS.}

Cryptococcus fagi, Barensp.

The increasing presence of this coccid in the Midlands is a matter that deserves more than passing attention. As I pointed out in last year's Report, p. 13, it is very desirable that, wherever it is noticed, it should at once receive attention.

During the past year a case was brought to my notice in Staffordshire. The VI Fluid has been applied, and although it is somewhat early to judge, it seems to have been successful in eradicating the insect.

Surrounded as we are in all the seven Midland counties by wooded estates, in which Beech figures conspicuously, I would impress upon all those who have the supervision of the same, not to neglect this pest, or it will assuredly spread over a large area, and treatment will become expensive and clifficult.

\section{THE FELTED ASH COCCUS.}

\section{Aptcrococcus frawini (Newstead).}

A Stafford correspondent forwarded twigs of Ash taken from an old tree with this Scale on.

According to Mr. Newstead, ${ }^{(r)}$ our leading authority on the Scale Insects of this country, it appears to be exclusively confined to the Ash (Fravinus excelsior).

In reply to this correspondent, I recommended that, if possible, the tree should be sprayed with the Vr Fluid, which had been used for the Felted Beech Coccus.

\section{THE HOP APHIS.}

Phorodon lutmuli, Schrank.

This troublesome and often serious insect pest has not been as plentiful in Worcestershire and Hereford as in past years. Personally, I am of opinion that this is, in a large measure, clue to the Winter spraying of plum trees. As the practice of Winter spraying becomes more general we shall undoubtedly see a diminution in the numbers of this pest; at the same time some more effective sprayfluid is necessary for the spraying of hops than is at present known.

(I) Monog. Coccidae of the British 1sles, 1003, vol. ii., p. 212. 
With this object in mind, various experiments hate heen made with a view to providing a Fluid that will confer immunity upon the plants against the attack of these insects for a number of das, without injuring the bine.

Whilst I believe the experiments are on the right lines and will ultimately prove successful, I have not yet arrived at any satisfactory conclusion. The experiments, however, will be continued during the coming season and duly reported upon.

\section{THE WILLOW APHIS.}

\section{Lachuns aiminalis, Fonsc.}

In July last I received some willow twigs from a Vorcestershire correspondent corered with this aphis. When examined in September the trees were perfectly free from this pest, although the ham it had done wais easy to see.

I am not aware that the life-history is known, but in the autumn I find that there is a general migration from the willows, probably to some other plant or plants, at present unknown. Sometimes, on appearing on some species of willows, little damage is done ; and the insects will then migrate to other species, which suffer considerably.

\section{THE WOOLLY APHIS. \\ Sclizoncura lamiscra, Hausm.}

This insect has been rery plentiful cluring the past year in all the Midland counties.

In $1896 \mathrm{Mr}$. I. M. Stedman ${ }^{(\mathrm{r})}$ published a full and interesting account of its life-history, and the present year has afforded me an excellent opportunity to work through this life-history in England, and compare it with the above admirable account.

For this purpose a garden containing some score of badly infested apple trees was selected, and futher observations have been made in numerous orchards, as well as in the laboratory.

\section{LHFE-HISTORY.}

Throughout the year there mily be found on the trees a somewhat oval shaped aphid of a purplish or reddish brown colour. This is the "Quecu-mother" which secretes the charateristic woolly material. She gives birth to living yomng, minnte, louse-lilie forms of al greyishyellow colour. These larvace, at first, live hencath the woolly secretion close to the parent; hut afler a time they ereep away, form great masses of wool, and produce it further gencration of living young. 'This mode of reproduction is continued throughout the summer, when a resting stage is reached, and pupice, or nymphs ippear, which give rise to winged forms. 
Stedman (p. 44) mentions that "towards the latter part of summer, winged agamic females are developed. In the station laboratory breeding cages, these winged forms first appeared on the twenty-sixth of August."

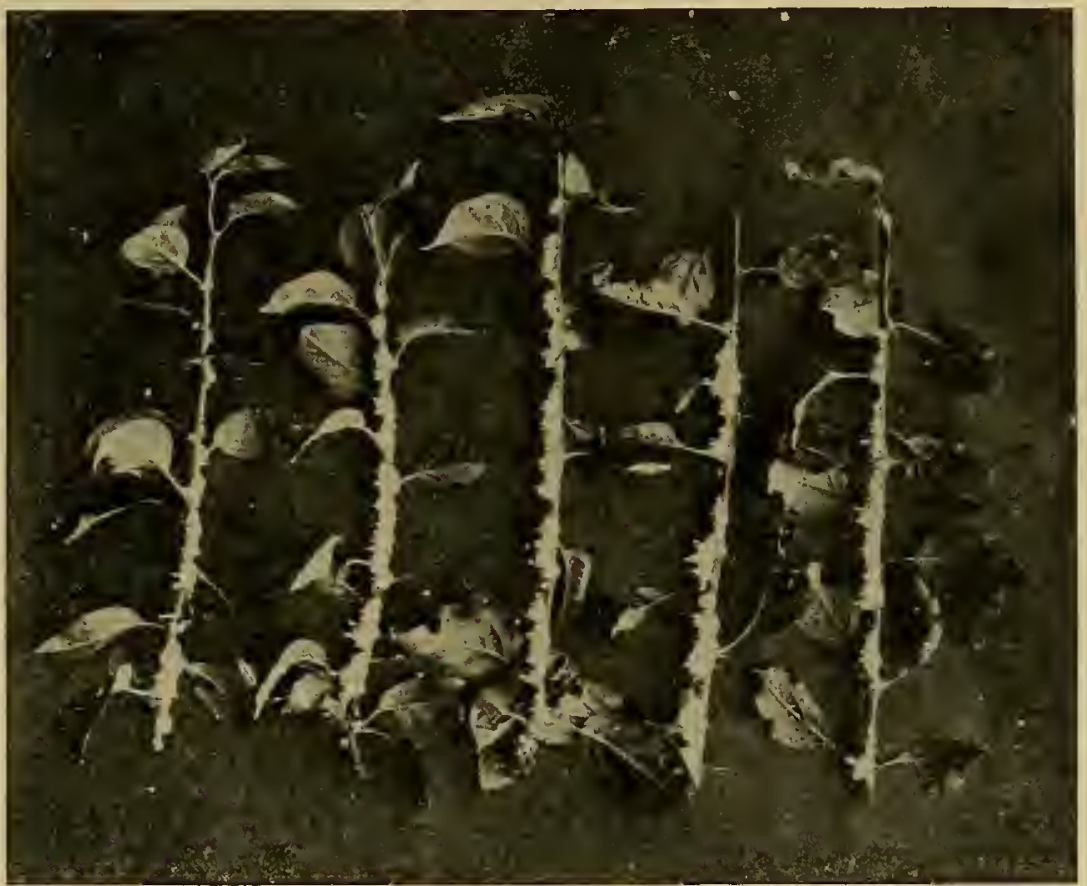

F1G. 7.-Apple Shoots attacked by the Woolly Aphis. (From a plotograph taken by Mr. J. G. Blakey, of Redditch.)

I have not been fortunate in meeting with many of the pupae or nymphs, but I have seen a fair number of the winged females. These latter fly from tree to tree and to other orchards. Here they produce living young, and continue to do so until the end of the autumn.

In the case under observation a wingless sexual generation was noticed early in November, fewer males than females, which latter are oviparous.

The sexual female is very small, and after depositing a single egg close to the base of the tree she dies, the egg is usually enveloped in the dead skin of the parent.

In the spring this egg develops into a larval form, which soon becomes a "Queen-mother" and produces living young.

Whilst the above cycle has been taking place on the branches of the tree, a similar one takes place amongst those forms living at the roots of the tree, excepting that no eggs are laid by the root forms. During the winter, many of the branch forms migrate to the roots, and in the spring they return to the branches. Stedman mentions that in Missouri the root form is the only one that does any injury, the branch form "being only occasionally seen; and when found, occurs only in small, unimportant, isolated colonies." 
These investigations are sufficiently important to reproduce in his own words, he states "The presence of the aerial form of the woollyaphis is readily detected by the bluish-white cottony looking substance that is excreted by and covers the greater part of each wingless individual aphis; and since these insects live in clusters or colonies, the patches of white matter are rery conspicuous, and can scarcely escape the notice of eren the most casual observer. It has been my experience to find in nature this aerial form in Missouri only in rare cases, and then only in those places where some injury had caused an abrasion of the bark; or some limb or twig had been cut or broken off; or where they had been crowded from the ground up to the base of the trunk; or on the suckers that had been allowed to grow around the tree. They are frequently artificially induced to attack the trunk by mulching, or by using wappers around the base of the tree as a protection against borers and rabbits. But whatever may be the cause of their presence abore the ground, the result is the same, namely; to cause an abnormal growth of the infested portion, resulting in the formation of a rough and pitted surface, and at times causing the cleath of the limb at the point infested. Horever, this injury is so slight in this state that it is insignificant in comparison with that found in the northern and eastern states, and especially in Europe, where apple trees are frequently killed ontright by this aerial form.

The presence of the root inhabiting form is readily detected by remoring the earth from the roots near the trunk of the infested tree. The appearance of a bluish-white cottony or mildew looking substance, or of linotty and distorted roots, will indicate its presence. It is this root or subterranean form that causes so much damage to the apple orchards in the southern half of Missouri, and to apple nursery stock throughout the state. The infested apple tree appears sickly; it cloes not grow as it should ; its leaves are less numerous and they have more of a pale green or yellowish color than is natural; and finally the tree dies outright or is blown orer with the first slight wind. Such are the ontward indications that a tree is badly infested with this pest. Sometimes the tree blows orer with a heary wind without slowing these ontward appearances in so marked a degree; but one soon becomes familiar with the appearance of infested trees, and can readily locate them before they are past recovery. In orchards, it appears that the great hulli of the clamige from this pest comes directly from the fact that the trees hlow orer so easily, the roots beaking off close to the trunk. Of comse this is clue to the fact that the roots have decalyed; and I am fully convinced from actual observation that ninety-five per eent of the calses of so-called "root-rot" in apple trees in this state is in reality the result of the attack of the woolly-aphis. In nusery stock, the dimige comes directly from the 
inability to sell badly infested trees, and not from the death of the trees themselves.

The woolly-aphis sucking the juices from the roots of the apple tree causes an abnormal growth of the attacked portion of the roots, resulting in the formation of gall-like swellings or excresences.

These swellings are usually irregular and knotty in appearance, and sometimes attain considerable size, while that portion of the roots between the excresences is frequently undeveloped.

The woolly-aphis will be found in large numbers, and in clusters, over the surface swellings, and especially between them in the numerous crevices that the larger excresences contain. The roots thus attacked, distorted and swollen, soon begin to decompose ; saprophytic fungi and bacteria enter the dead and decaying portions and help to hasten the work, and soon that portion of the root perishes. Sometimes the root seems to be killed outright by the vast number of aphis sucking the sap and causing the abnormal growth; so that the attacked portion perishes before decomposition has fairly set in. But in either case the aphids perish, or leave the dead root and seek living roots upon which they can feed ; and hence, when one examines a root that has been dead for only a short time even, the aphis may not be found there, and this has led many to attribute the death of the root to other causes, especially to 'root-rot.' As the woolly-aphis attacks in immense numbers the main roots at or near the trunk, and as these roots are usually eventually killed and then rapidly decay, the tree loses its support and falls with the first wind."

There is a wide-spread opinion that the root form and that in the branches are two distant species, but there seems little, if any, evidence to support such views. With reference to this, Mr. Stedman carried out the following experiment:-

"On the fourteenth of March, seedling and one-year-old apple trees were planted in the root-cages. The plants were first thoroughly cleansed of all insect life, as eggs, etc., and the earth used was specially prepared and free from insects and their eggs. On the sixteenth of March, wingless, agamic female woolly-aphis, just obtained from the roots of an infested apple tree, were placed on the roots of the sound trees in four of these cages. These root-cages are kept isolated in one room of the green-house, two of them in large breeding cages made of glass and very fine wire gauze, so that no insects could escape or others possibly enter. The apple trees soon put forth leaves and grew well. The aphids multiplied rapidly and not only formed colonies where introduced on the roots, but they soon spread in small numbers over the greater portion of the roots, established colonies near the trunk, and crawled up to trunk and on to the branches, where they multiplied rapidly and established flourishing colonies. These colonies can be seen on the branches as well as on the roots of the 
young trees, photographed in figure 3. The aphids exist in reality in small numbers on all parts of the young apple trees, but do not appear in the photograph except where they exist in colonies. Some weeks after this photograph was taken, the entire trees, stems, roots, and eren the petioles and midribs of the leaves were white with woolly-aphis. The insects appeared to thrive as well in the open air as in the soil, and in these cases both the root and limb forms were derived from the same parent.

But in order to determine whether or not the limb form would spread to and infest the roots, some woolly-aphis from the limb of an infested tree in Jaclison county were obtained and introduced, June 28 th. on the limbs of the young apple trees in the two other root cages. The trees contained no insects except those placed on the limbs. The rootcages were isolated in large breeding cages in the greenhouse. In the course of a week the aphids had established flourishing colonies on the branches, and at the expriration of a month they had spread down the trunk in scattered and isolated places, and in one case had attacked the roots near the trunk. In two weelis more the roots of all the trees had several well established colonies upon them.

From these observations and facts it is believed that what little of the aerial or limb form of the apple tree woolly aphis we have in this state is now derived from the root form. Of course it will be unclerstood that I clo not imply by this statement that the original form of this aphis was root inhabiting, for I am decidedly of the contrary opinion."

Apart from the great clamage these pests clo to fruit trees, by draining the vitality, the rounds formed hy their punctures ultimately expose the trees to fungus attaclis. Whererer these punctures occur on young wood, there is an abnomal growth of the tissue, which talies the form of rounded or irregular swellings. Later, these grall-like lumps split (and are often stated to he "canlier"), and it is in these splittings that fungi and other pests lind lodgunent.

\section{PREVENTVE AND REMEDIA MEASURES.}

So long as people are allowed to neglect their orchards, or eren a few trees, this pest will he with us, and call only be controlled by excreising most drastic treatment.

In an orchated adjoining the one mentioned above, the following treatment was followed out in 1907, and although only a few yads from trees worse affected than I halle cree seen hefore, it now remains comparatively clean.

In Jimbary the trees were sprated with the Vi Fluid. In December the soil around the trees vats taken atrats and without actually touching the roots, Apterite was seatlered all aromel. It is proposed to grice all the trees a dressing with the l'z Fluid early in the Spring. 
If this treatment is persisted in I think the pest will be held in check, but it is most important that the roots of the trees should be treated as well as the branches.

Spraying in the Autumn is of little, if any, use, for as fast as the trees are cleaned, winged females from trees in other orchards re-infest them.

\section{THE FRUIT TREE ROOT LOUSE.}

Schizoneura fodiens, Buckton.

Early in the year a Worcester correspondent forwarded specimens of this insect, from the roots of Red Currants, and later I received it from the same county on the roots of a young apple tree.

It has long been confounded with the root form of the Woolly Aphis (Schizonemra lanigera.)

In the first case Vaporite was employed and proved fairly successful; later, in the second case, experiments were made with Apterite which proved most effective.

\section{THE APPLE SUCKER.}

Psylla mali, Schm.

Experiments with the $V_{I}$ and $V_{2}$ Fluids have been continued on the eggs and larvae of this insect, and most satisfactory results have been obtained.

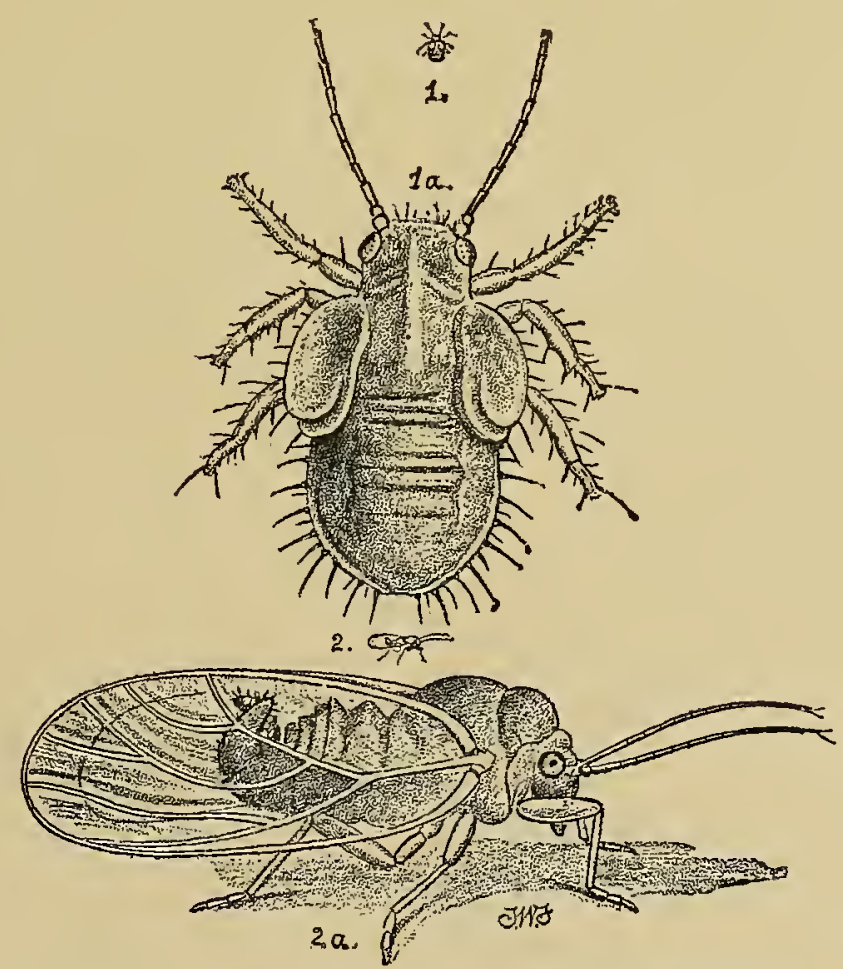

Fig. 8.-The Apple Sucker (Psylla mali).

I.-Larva, natural size. I $a$.-Larva after third moult, much magnified.

2.- Perfect insect, natural size. 2a.-The same, much magnified. 
A number of demonstrations have been given showing the action of the former fluid upon the eggs. A little of the VI Fluid was taken and mised with one-hundred parts of water, then a few perfect eggs were placed on a glass slide under a low power of the microscope. After making sure that these were in no way damaged, they were wetted with the Fluid by means of a line camel hair hrush. Within a few minutes the protoplasm was seen to contract, often spurting through the hroad end of the egg, the eggr-shell becime wrinkled and instead of a smooth, tense membrane, it lay as a crinkled sac with a roush or broken surface.

In most cases this action was clearly observable within three-anda-half minutes after the Fluid was applied, but in no case did it exceed twice that length of time.

As I have elsewhere stated (p. 7) the experiments, both in the laboratory and on the actual trees, with the lime and salt sprayfluid were most unsatisfactory.

\section{THE ASH PSYLLA.}

Psylla ficavilit.

From Staffordshire and Worcestershire correspondents, many inquiries have been received respecting this insect. In one case the attack was extremely bad.

Wherever I thought spraying was practicable or likely to be carried out, an application of the $\mathrm{V}_{2}$ Fluid was recommended, and not having leard anything further of the pest, I presume that it has proved successful.

In nearly all the abore cases the cause of the mischicf had heen allowed to continue year after year without any remedial measure being applied; and considerable ham must have been done to the trees, most of which were, fortunately, young ones.

On numerous estates that I linow of, forest and ornamental trees are badly neglected. It is surely a wise policy on the part of those who have the care of such, as also on the patt of the owners, to see that they are liept as free from discase and pests as possible.

\section{THE MAY BUG.}

\section{l'hylloperlhar horlicola, Limn.}

i Mambielishire correspondent forwareded specimens of this hectle from a fick of swedes, where they were present in sreat numbers. fortmatcly, Rooks and staliugs in flocks were attracted by the abund:mece of food :usd soon lessened their numbers.

Lilie the Cockehafer, to which they are related, they can he controlled hy the application of a soil fumigamt. 


\section{THE PEA BEETLE.}

\section{Bruchus pisi, Linn.}

Two or three correspondents have complained of the damage done to peas by the larva of this beetle.

\section{LiFE-History.}

The female beetle deposits her eggs on the young pods, and, upon hatching out, the larva bores into a pea, and passes its larval stage, eating a large cavity in the pea. In this it pupates, the beetle emerging in the following spring. Sometimes the beetles make their way out of the peas in the autumn, and pass the winter elsewhere.

In other cases they remain within the peas, only issuing after the latter have been sown.

A closely allied species B.rufimanus, attacks beans in a similar manner.

\section{Preventive and Remedial Measures.}

Peas which are or have been infected should not be used as seed, even when they are kept in closed vessels and the beetles have left them and died, they seldom produce strong plants.

Fumigation with bisulphide of carbon is perhaps the best method of killing the beetles.

Care should be exercised in purchasing seed, to see that it is free from this pest.

\section{THE APPLE BLOSSOM WEEVIL.}

Anthonomus pomorum, Linn.

Various correspondents have sent in examples of this beetle, or have written complaining of the damage it has done.

A full account of the life-history was given in my Second Annual Report, p. 2 I.

An experience of this beetle, now extending over many years, inclines me to the opinion that it is always most plentiful in neglected orchards. Where the trees are not sprayed in the Winter, and the moss and lichens are allowed to grow, there the beetles find a secure place for hibernating in. In a like manner in orchards where dead leaves, long grass, etc., are present, they provide favourable conditions.

Winter spraying, quite apart from the numerous eggs that are destroyed, will pay the fruit-grower, if only by reason of keeping the bark clean and free from all mosses and lichens, beneath which this and many other pests of fruit trees hibernate during the Winter months.

\section{THE CABBAGE GALL WEEVIL.}

Ceuthorhyuchus sulcicollis, Gyll.

Throughout the Midland counties there has been a distinct increase of this very troublesome insect, and cabbages and turnips have consequently suffered. 
Clean cultiation is all-important in dealing with this pest. In the early part of the year it lives on charlock and other cruciferous weeds, later passing on to cabbage and tumip crops. It is most important that all sucl weeds should be destroved. Further, all infected cabbage stallis and turnip peelings should he hurnt, and not allowed to rot in heaps on the ground.

I have not yet had an opportunity of experimenting with Apterite on this pest, but I think it will be found an effective remedy:

\section{THE TURNIP SEED WEEVIL.}

Comlhorlyuchus assimilis, Payk.

A Staffordshire correspondent forwarded Turnip seed badly infested with the larvae and pupae of this tiny beetle.

Seed merchants know it as a most destructive pest, for pods which have been attacked, contain few; if any perfect seeds.

In a sample of seed sent, the fat, yellowish-white lariae were present; also cocoons composed of asglutinated seeds, inside each of which I found a pupil.

This beetle attaclis other cruciferous plants in a similar manner.

Seed known to be attacked should be fumigated with bisulphide or carbon (See P. 56).

\section{THE PINE WEEVIL.}

\section{Hybins ubictis, Fabr.}

The insect is one of the commonest, and at the same time, one of the most destructive to pines we have in this country. Personally, I have no experience of it aluat from pine, but it is known to attack other conifers, as well ats oak and other trees.

\section{LIFE-HISTORI:}

The heetles swarm from May to fune, and beed on to September. The eggs are deposited on the stmmps and roots of the pines.

They hatcl out in from fourteen to twenty-one disys, and, until well on in the antumn, form their chancteristic hurows : passing the winter at the end of these hurows. During the first year they feed upon the bist and sipmood ; so that, so fir ats the lamal stige is concerned, they do little damage. Pupation talies place late in the following spring, in the roots of stmmp, and the perfect insect appears irom Mity lo Seprember.

Phose which emerge in the spring snate the hark of the roung plants, thus allowing the resin to exude. In some cases the trees become almost completely peceled.

During the winter, the aclults hiberuate in hollow stmmps, amongst deat leatres, under sticks of wood, elc: 
Preventive and Remedial Measures.

It has been shown, in this and other countries, that forest clearings are particularly favourable harbouring spots for this beetle. It is therefore most important that all useless material should be burnt, and the felling area moved from time to time.

Whatever can afford a breeding place, unless employed as traps, should be cleared away, such, for instance, as waste timber of any description, broken bark, small fragments of wood, pieces of roots left in the ground, dying trees, etc., etc.

Log Traps placed in June are useful. Pieces of pine or spruce, 3 or 4 feet long, and 3 or 4 inches thick, should be cut and so buried in the ground that they protrude two or three inches above the surface. Such traps should be placed from 40 to 50 feet apart, and carefully taken up and burnt in September.

Feeding sheep in the clearings is recommended, as their droppings are obnoxious to the beetles.

\section{THE OSIER WEEVIL.}

Cryptorlyynchus lapathi, Linn.

Both the larvae and adult beetles have been received from different correspondents, with complaints of their injury to osiers and willows.

\section{LIFE-HISTORY.}

The female lays her eggs in small holes which she bites in the rods, a single egg being placed in each hole. In from 18 to 2 I days the larvae hatch out as small whitish grubs, and immediately commence and burrow round the rod. In some cases this burrow encircles the rod, in others it extends only part way around; whilst occasionally it is irregular, passing slightly upwards or downwards. In all cases the larva ultimately tunnels inwards to the pith, where it clears a chamber, which usually extends for four or five inches and sometimes even more. This central chamber is connected with the exterior by a less carefully formed tunnel, and through the opening of this latter the bits of gnawed wood, etc., are passed out.

When full fed, the larva measures about one third of an inch in length, and early in August it pupates, the beetles hatching out towards the end of that month, or early in September. During the winter the beetles hibernate in the stools, in the chambers formed by the larvae, and amongst rubbish.

\section{Remedial Measures.}

The same as employed for Willow Beetles, which see.

\section{WILLOW BEETLES.}

Three species of beetles, known as common pests to osiers and willows, were forwarded by a Warwickshire correspondent; these were 
the Brassy Willow Beetle, Phyllodecta zitcllinae, Linn., and its ally P. inlsalissima, Linn., and a species known as Galcrucella lincola.

In flood refuse, heaps of osier peel, or collections of dead leaves, all three species are very common. It is amongst such material that they hibernate during the winter.

The first mentioned species is perhaps the commonest, a short account of its life-history may therefore be useful.

\section{LIFE-HISTORY.}

The life-history here described was worked out upon some material taken in February last from the stump of an old willow: There were large numbers of the beetles present, and early in April the females deposited, on the undersicles of the willow leares, isolated groups of tiny spindle-shaped eggs, each group being covered with an irregular, transparent cover.

The larvae hatched out in seven days and were of greyish-yellow colour; when full fed they became slightly darker in colour and had four conspicuous brown spots on the dorsal side of each segment, with smaller ones laterally; whilst the two most posterior segments were marked with a black square. The first three segments were the most prominently marked, and also the largest segments, the posterior ones narrowing.

In the laboratory the larvae fed on the undersides of the leares for some weeks, linally falling to the ground and pupating in the soil.

The beetles hatched out at the end of August, and fed on the leaves so long as we could ohtain any, ultimately hihernating in the dehris of the willow stump.

\section{Preventive ani) Remedial Measures.}

All material, such as mentioned ahove, which is likely to afford suitahle guarters for hibernating in, should he hurnt or removed.

Spraving with Paris green, or Arsenate of lead, will kill the larvae and heetles in the spring.

Dusting the stocks with line and soot hats also been found efficacious.

\section{THE CIGAR BEETLE.}

Lasioderma lestacen, Duf.

Quite a mumber of inçuiries have heen receised as to dimage to Havana and Cuban cigars by this beetle.

One gentleman assured me that it came into his stock with some Halanla cigars about two years agn, and since had made its way from hox to hox. Borings in the hoxes certanly supported this view.

Hoping to eradicate what was proving a very serious pest, I recommended fumigation with hisulphide of carbon, (see p. $5^{6}$ ) and I am pleased to learn that this has prosed effective, for no further damilge has heen notieed. 


\section{THE WOOD LEOPARD MOTH. \\ Zeuzera aesculi, Linn.}

A Worcestershire correspondent forwarded the larvae of this moth in August, which were attacking young apple trees. Although not sufficiently common in the Midland counties at present, it might, in a favourable season, become a serious pest to fruit growers.

\section{LiFE-History.}

The moth appears in June, and the female deposits a large number of oval orange-coloured eggs upon the stems and branches of various trees. Saplings seem particularly liable to attack.

The eggs hatch in a few days and the larva bores into the sapwood, remaining in the woody tissues during the first winter. In the following summer it bores a gallery in the middle of the wood, here it passes its second winter. About May it passes beneath the bark, where it pupates, the moth emerging in June.

The larva, when full-fed, is nearly two inches in length, in colour a yellowish-white, with black spots on each segment. The second segment is covered with a dark brown dorsal plate.

Amongst the various trees attacked by the larvae of this moth we may mention the apple, pear, plum, ash, aspen, beech, birch, elm, hawthorn, holly, horse-chestnut, oak, poplar, privet, quince, walnut, willow.

\section{Preventive and Remedial Measures.}

Cutting off and burning all infested branches is the only practical treatment. Badly infested trees are best cut down and burnt.

Numerous small birds feed upon the eggs.

\section{THE GARDEN SWIFT MOTH.}

Hepialus lupulinus, Linn.

The larvae of this moth have been forwarded by different correspondents as damaging strawberry plants, celery, winter beans and various flowering plants.

The habits and methods of attack are very similar to those of the Turnip Dart Moth; and the same remedies hold good.

\section{THE LAPPET MOTH.}

\section{Lasiocampa quercifolia, Lini.}

A Worcestershire correspondent forwarded the larva of this moth in August last, taken on hawthorn. The large size of the caterpillar 
excited his attention, and the following account of the life-history was forwarded :

"The specimen forwarded is the caterpillar of the Lappet Moth, which has previously been found in the locality mentioned.

The eggs are laid cluring July or early in August, on the underside of the leaves of hawthorn, sloe, willow, blackthorn, apple, plum, etc., in groups of twos, threes, and fours, or more. The larvae hatch ont in from twelve to fifteen days and feed for a short time. Early in the autumn, however, they make their way down to the lower stems, where they winter. Specimens reared in confinement, measured about an inch in length at this period. With the return of spring they commence to feed again, and when full-fed are nearly four inches in length.

Pupation takes place from June to August, the dark blackish-brown chrysalis being enclosed in a grevish-brown silky cocoon. In confinement I have always observed that the cocoon is large and ill-fitting; but in nature it is said to be a tight-fitting one.

The moths appear from June to August.

Whilst there are cases on record of the larvae of this moth clamaging fruit trees, it is scarcely sufficiently common to constitute a pest."

\section{THE CURRANT OR MAGPIE MOTH.} Abraras grossuluriata, Steph.

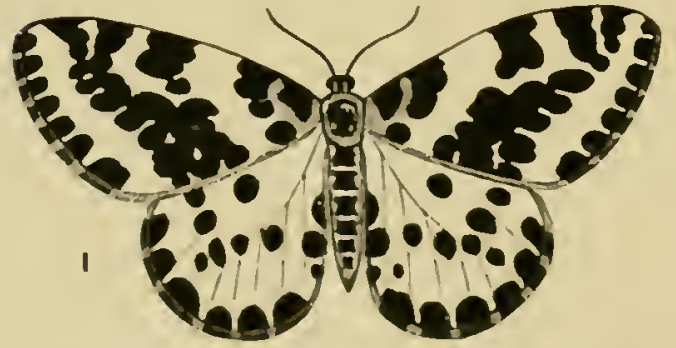

Fig. 9). -THE CURRANT OR MAGI'HE MOTH.

Very few cases of a serious nature have been reported during the past season. Some few years aso this looked like becoming a very serious pest to growers of gooseherries and currants. Attention was repeatedly called to this fact ; and full particulars respecting preventive and remedial measures were sent out to a large number of growers, urging upon them the importance of taking some action.

It is sincerely to he hoped that their efforts will not he relaxed now that it hat been lessened in numbers. I would also, in this connection, draw the attention of owners of private gardens to this pest which ustally Hourishes there. It is quite possible on small areas to effectually cradicate it hy hatd-picking.

\section{THE WINTER MOTH.}

Cheimatobia brmunalor, Limn.

Judging from the decrease in the number of incuiries respecting this insect it would seem to have been less prevalent than in previous seasons. This is mo doubt accounted for hy the fact that many growers 
who were becoming alarmed by the rapid increase, decided to spray with the Caustic soda-emulsion early in I907. Many have written me stating what an excellent effect this had.

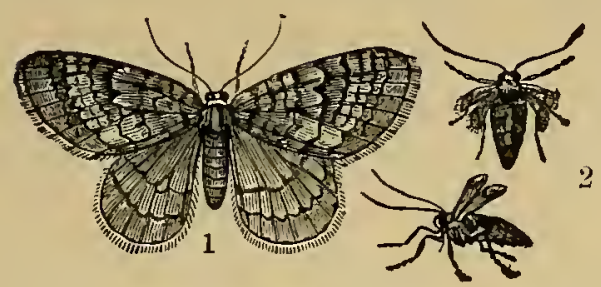

Fig. IO.-The Winter Moth (Chcimatobia brumatal).

Owing to the more general adoption of winter spraying, growers have abandoned grease banding their trees, at the best only a partially effective remedy.

In the Evesham and other districts there should be no difficulty now in keeping this pest under control.

Wherever the moth is known to less female. Natural size.

be about, spraying should be deferred until the end of Jantiary. I have known cases where the apple trees have been sprayed in December, and left in a beautiful and healthy condition, but have later been visited by the female moths, and the result has been a plague of caterpillars in the following spring, much to the growers surprise.

\section{THE TURNIP DART MOTH.}

Agrotis segetum, Schiff.

I mentioned in last Report (p. 25) what a destructive pest this insect had become in the Midland Counties during 1906, and there has been no falling off in the number of complaints during the past year.

I had hoped with the aid of Vaporite to be able to cope with the larvae of this moth, but frequently I found that the material was not put in deep enough, hence the fumes only destroyed those near the surface.

A series of experiments made with Apterite gave splendid results. The active principle from this material working both upwards and downwards, made it a most thorough fumigant.
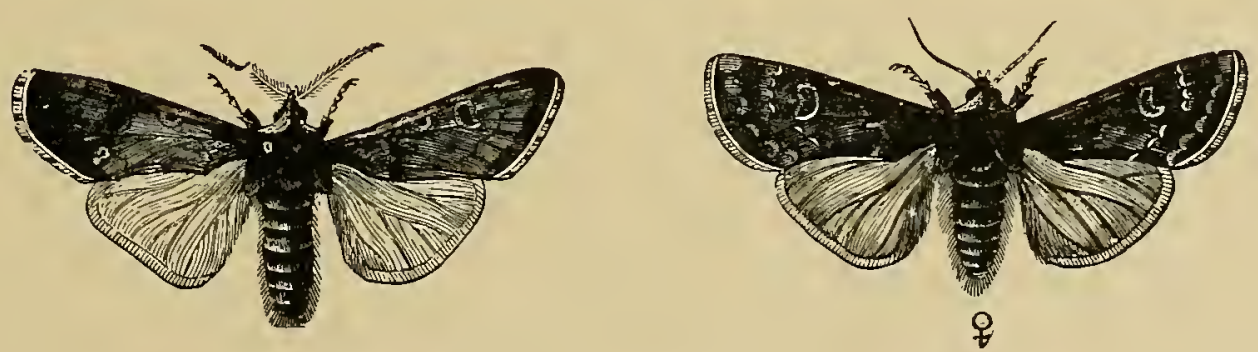

Fig. il.-Male and Female Turnip Dart Moths.

In one case where oak and ash seedlings were very badly attacked by the larvae of this moth, the Apterite was dibbled in about seven or eight inches deep, between the lines of plants, many of which were rapidly dying. There was an appreciable change noticeable in a few days ; and when, after a week, some of the plants were taken up there was a healthy growth of new rootlets to be seen. 
In forest nurseries a soil fumigant of this kind must prove of great value.

\section{THE HEART AND DART MOTH. \\ Agrotis c.rclamationis, Linn.}

As in the case of the last mentioned species, there has been an appreciable increase in the number of cases reported in which the larvae of this moth have been doing serious damage.

The habits and life-history of the Heart and Dart Moth are very similar to those of the Turnip Dart Moth, described in my Fourth Report (p. 25,) and the treatment also.

Various experiments have been made with soot, soot and lime, kainit, gas lime, etc., scattered on the land; poisoned baits, consisting of bunches of clover, etc., that have been steeped in a solution of Paris green, and then distributed about the field have given fairly good results, but such a method is risky owing to the possibility of live-stock eating the same.

THE GREAT YELLOW UNDERWING MOTH. Triphacua promuba (Limn.).

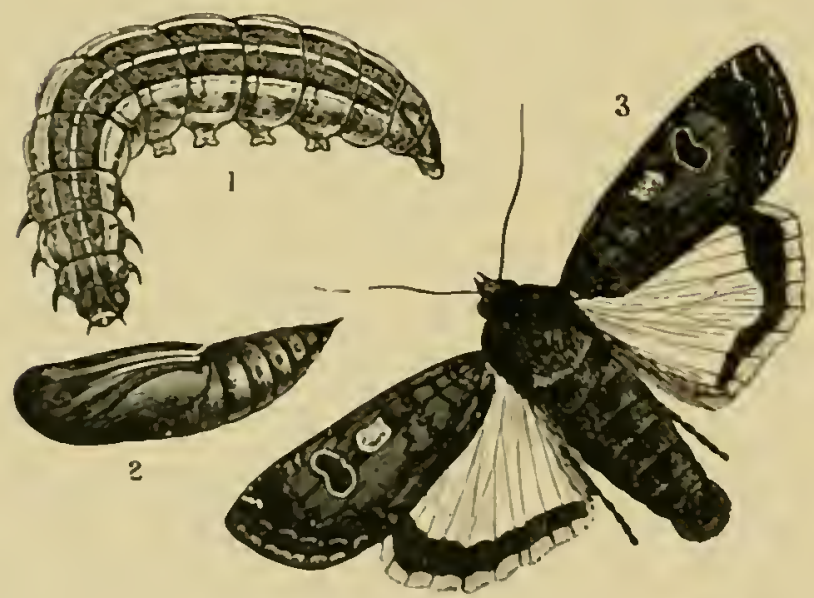

loIG. 12.-THE GRFAT YELLOW LNDERWING MOTH. 1.-1.arva. 2.-Pupa. 3.-Moth.

The larvae of this moth have proved rery troublesome to horticulturists and others during the past season. In private gardens it has been especially numerous and has done a large amount of damage.

The life-history briefly indicated in my Second Report, (p. 37.) may he usefully repeated.

The female deposits her eggrs in July and August at the roots of different plants, the larvae hatching out in about fourteen days. They are nocturnal feeders, and lie hiclden in the surtace soil or beneath the roots of their food-plants cluring the diyy. Through the winter months they seem to lie dormant; but on the return of spring or mild-weither, they commence to feed agrain. Most of them hecome full-fed towards the end of April, or early in May, when they bury themselves and turn into pupac, the moths emerging towards the end of June or carly in July.

\section{Remedal Measures.}

In gardens, stirring the surface frequently during the winter and spring destroys some of the larvate; and exposes others to the attack 
of birds. Starlings are particularly fond of them. Handpicking the larvae is still more effective. I have entirely cleared them out of my own garden in this way.

Fresh gas lime worked into the land in autumn has been tried with some amount of success.

Apterite proved an admirable remedy, destroying this and other ground larvae without in any way damaging the plants.

\section{THE APPLE LEAF MINER.}

Lyonetia clerckella (Linn.).

Two cases of serious damage to apple trees by the larvae of this small Tineid moth have been reported on. The leaves on the trees were mined in all directions ; and three or four larvae in each leaf were not at all uncommon. As a result, most of the leaves fell at the end of July and early in August.

I know of only one record of this species damaging to any appreciable extent the foliage of fruit trees; that is one mentioned by $\mathrm{Mr}$. Fred. V. Theobald ${ }^{(x)}$ as occurring in Huntingdonshire.

The life-history is described by the same author and the following abbreviated account is taken from his description.

The female, as a rule, deposits a single egg on each apple or cherry leaf. From this the larva hatches and bores into the leaf, feecls upon the soft tissue, and forms a sinuous tumnel, which gradually enlarges as the larva increases in size. The larva varies in colour from pale to deep apple green. The period of larval life varies; some were mature in four weeks after the tunnels were first noticed; others not until five weeks.

When full fed, the larvae eat their way out of the tunnel and crawl upon the leaf, forming a cocoon on the upper, or more generally, lower side of the leaf. The pupal stage lasts from ten to twenty days. Three or four broods occur in a year. During the winter months the moths hibernate in crevices, under rubbish, etc.

Preventive and Remedial Measures.

In the two cases referred to above, hand-picking and burning the leaves proved successful.

\section{THE APPLE ERMINE MOTH.}

Hyponomenta malinella, Zell.

Thanks to the combined action of numerous fruit growers, and to many correspondents possessing only a few apple trees in their kitchen gardens, this pest has been considerably reduced in the Midland counties.

(I.) Second Rpt. Econ. Zool., 1904, p. 37. 
In quite a number of cases where this moth was present on apple trees in private gardens, the tents werc collected and destroyed, and winter spraying was resorted to, often for the first time. The time, trouble, and cost, in no case was serious, but the benefit conferred upon the fruit growing community by this wise and thoughtful action must have been considerable.

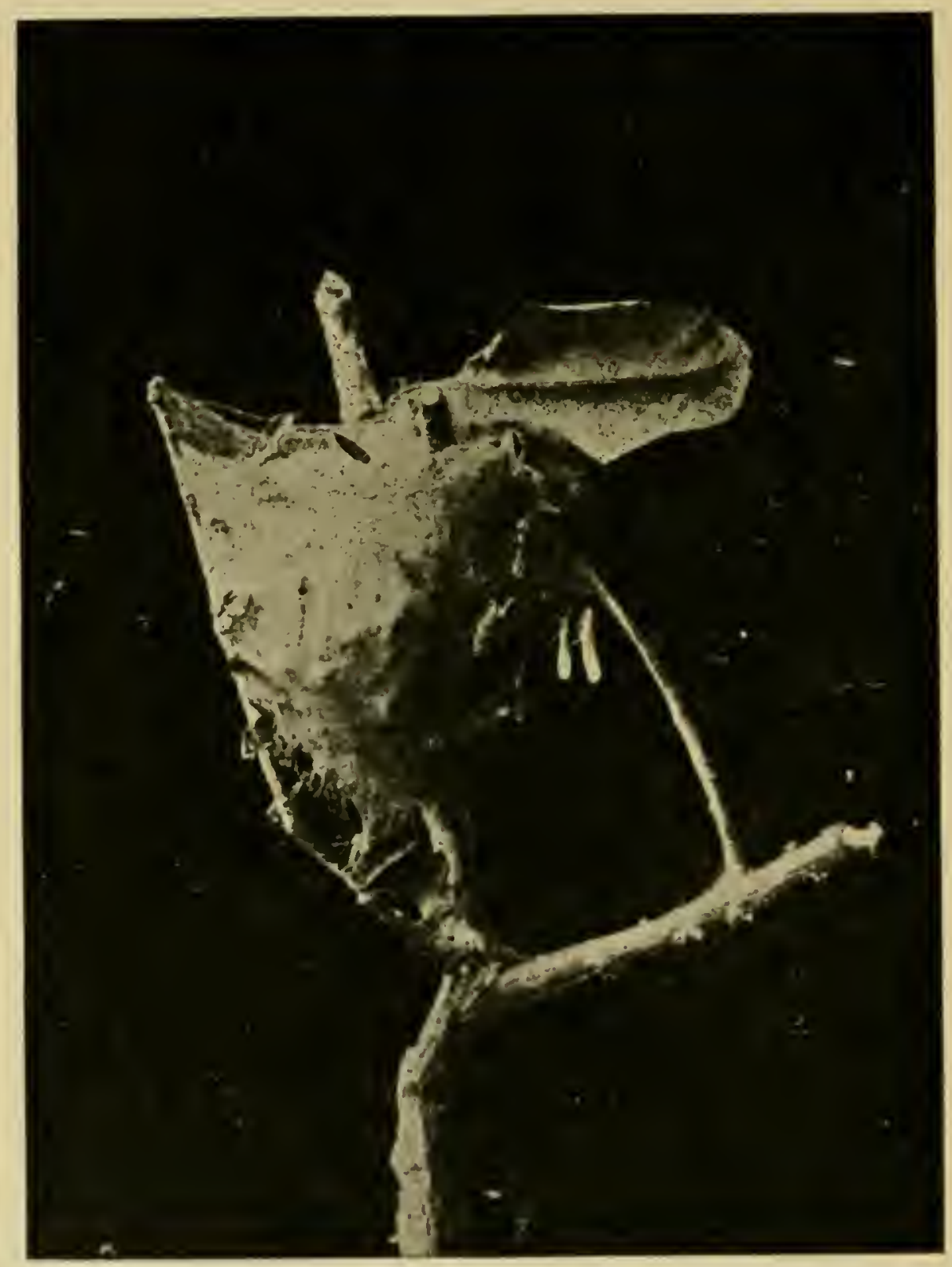

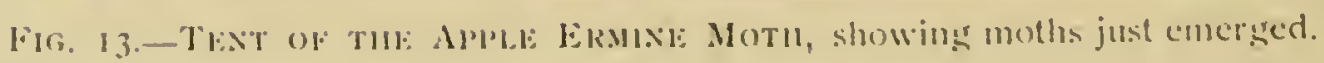

Private girdens are often a considerable source of clanger to the fruit grower; but a direct and tactful representation to the owners I find seldom fails in specdily removing the musance. Of course there are cases where a stubborn and indifferent attitude is maintaned; and it is difficult to know how to deal with such thoughtless and selfish people. Fortunately, in the Midlands, they are few and far between. 


\section{THE RASPBERRY GALL MIDGE. Lasioptera rubi, Schrk.}

Two cases of the occurrence of this Gall Midge have been reported upon. The first was found on brambles, but only very few galls were present.

The second case, and the most interesting, was a bad attack on raspberry canes. Here the galls were numerous and large, the largest measuring over an inch across. The grower informed me that he had noticed a few in the previous year, in consequence of which there was little or no fruit during the past season.

\section{LIFE-HISTORY.}

About the end of May, or early in June, the female fly deposits her eggs, eight to fifteen in number, at the base of the buds. These hatch out in from eight to ten days, and the young larvae at once commence to make their way through the epidermis. After a short time, a distinct swelling appears; the holes formed by the larvae in the epidermis are closed from within ; and the gall, as it is now termed, commences to thicken. Within the gall the larvae feed, becoming fullfed in the following April. The larvae, like those of many Gall-Midges, are a bright orange colour, or orange with a faint tinge of red. Early in May pupation takes place and the flies appear at the end of May, or early in June.

\section{Preventive and Remedial Measures.}

Winter spraying with the VI Fluid will probably penetrate the galls and kill the larvae.

Spraying the canes with soft soap and soot will prevent the flies depositing their eggs.

Cutting off the galls and burning the same will of course lessen the pest, but this is a somewhat difficult task on a large area.

\section{THE ASH CAULIFLOWER GNAT.}

\section{Cecidomyia fraxinella, Meade.}

This minute fly has been particularly plentiful in the Midland counties during the past year, disfiguring young Ash trees.

It is a small brownish-yellow insect, with black head, and covered with minute hairs.

Described originally by Dr. Meade ${ }^{(x)}$ as belonging to the genus Diplosis, owing to the characteristic antennae, but resembling Cecidomyia in that the direction of the cubital vein more resembles the condition obtained in this last mentioned genus. This author was of opinion that it was probably the same insect as the one described by Winnertz, under the name of $C$. minnta, ${ }^{(2)}$ a view, however, from which I must 
differ. I think there is very little doubt as to its being specifically distinct from that species.

\section{THE WILLOW MIDGE.}

\section{Cecidomyia rosaria, Liv.}

The rose-shaped galls formed by the larrac of this tiny midge have been received on various species of willow:

It has been particularly prevalent during the past year; but it can scarcely be described as a pest, as the damage is extremely small.

\section{THE PEAR MIDGE.}

\section{Diplosis pyrivora, Riley.}

For the first time for many years I am able to record a diminution of this pest in many orchards where hitherto it has been very plentiful. This improvement has been brought about entirely by burying the surface soil.

During the year I have made a number of experiments on the larvac and pupae.

In June last Mr. J. Lees sent me, from Kent, some larrae and pupae which were dipped in the VI Fluid, I in Ioo, the larve were killed in about fifteen minutes, and the pupae in about thirty-five. Mr. Lees suggested, as a result of this experiment, that possibly it might be worth while saturating the sround, say about the end of May, beneath affected trees.

A sccond experiment with Apterite points to a more practical remedy; howerer; full particulars of which I hope to give in a later Report.

\section{THE ONION FLY.}

Phorbia ceparmm, Bonché.

Although I have had only a single case of this pest reported by correspondents during the past year, two of my Voluntary Observers have sent in long accounts of the mischief done in Warwickshire and Staffordshire.

\section{LIFE-HISTORY:}

The female fly" deposits her eggs on the young leaves of the Onion, close to the earth. The larvac hateh out in a few dass, and malie their way into the bise of the bull, where they feed for two or three weeks. Miss Ormerod states a fortmight, hut I have notes of a citse where the larvac were in the bulbs for nearly a month. They then pass out of the bulb into the soil, and there change into pupac, from which the flies issue in about fourteen dass, and again attack the plants which had previously escaped. Given faromable weather, and the requisite food plint, there may he three or four broods. 


\section{Preventive and Remedial Measures.}

Wherever an infestation has been experienced, onions should not be grown on the same ground the following year. The soil should also be deeply ploughed or trenched, and an application of Apterite given.

The remedies which have been recommended from time to time are very numerous, but mostly ineffective ; amongst these may be mentioned watering the rows with paraffin oil and water, soap-suds, houseslops, and liquid manure ; dusting with gas-lime, soot, charcoal dust, etc.

\section{THE FRIT FLY.}

Oscinus frit, Linn.

In the Midland counties, and generally throughout the country, the larvae of this small fly have been particularly plentiful; and oats and barley have suffered to a considerable extent.

\section{LIFE-HiSTORY.}

The flies appear from April to May, the females depositing their eggs on the leaves of the young plants. On hatching, the larvawhich is a small, fleshy, legless maggot-makes its way to the lower part of the plant, and thence into the centre of the stem, subsequently pupating there. About the middle of July the second brood of flies appears; and the females lay their eggs on various grasses, and, if sufficiently developed, in the ears of oats and barley.

The third brood of flies appears in August or September, the females depositing their eggs on different wild grasses, and the flies from this generation issuing from the puparia in the following spring.

\section{Preventive and Remedial Measures.}

The importance of early sowing will at once be fully recognised, and the advantage of a dressing of artificials to stimulate growth.

Wherever an attack has been noticed the previous season, the land should be ploughed with a skim-coulter attached; or deep ploughing resorted to.

Oats and barley should be planted the next season as far away as possible from areas previously affected.

All wild grasses should be destroyed.

\section{THE CARROT RUST FLY.}

\section{Psila rosae (Fabr.).}

The last bad attack we had of this fly in the Midlands was in 1902 and 1903 , since, I have had few cases until the past season, during which they have been somewhat numerous. 
The following brief account of the life-history is repeated from my First Report, p. ro :-

It makes its appearance in the early spring and lays its eggs upon the carrot roots just below the ground, upon hatching out the larva, which is nearly a quarter of an inch long, without legs, and yellowish in colour, with the anterior end pointed, makes its way into the lower part of the carrot, and then commences working upwards, making passages in all directions. Leaving the carrot it goes into the earth and pupates. The last generation remains in the pupal stage until the following spring.

From the different accounts which have been given of the lifehistory, it is evident that there is much variation and great irregularity in the development.

\section{Preventive aNd Realedial Miaslires.}

When the plants are singled the soil should be closely pressed around the root, so as to prevent the flies depositing their eggs there. Heary watering has also been recommended for the same purpose.

Sand or ashes saturated with paraffin, scattered over the young plants, tends to keep the flies off them. Watering with paraffin and water, I gill of the former to I gallon of the latter, after thinning has also proved successful.

A dressing of gas-lime dug into the soil before sowing has answered in many localities, as also strong liquid manure when the flies are first noticed.

An application of Apterite to the land will probably prove the most effective method of treating this pest.

\section{THE GOUT FLY.}

\section{Chlorops tacniopus, Meig.}

In Worcestershire and Warwickshire, wheat, barley, and rye, have been badly attacked by "Gout."

\section{LIFE-HISTORY,}

The long, greenish-white eggs are deposited hy the female, early in May, on the sheathing leares of the developing ear. On hatching out, the larva pierces its way through the leaves, eating into the base of the ear, upon which it feeds. Later, it malies a chanuel down the stem to the first node or joint, and there pupales bencath the leaves. The lly appears in about twelve or fourteen days.

Phere are two broods in a year, the second one laying its eggs upon wild grasses.

In some of the infected wheal I eximnined, only at single larva was found in each stem. In ofhers, howerer, not apparently attaclied much more severely, there were two, and in a few cases, three larvat 
Preventive Measures.

The only measures that can be taken are those of a preventive nature.

As in the case of the Frit Fly, early sown crops are less liable to

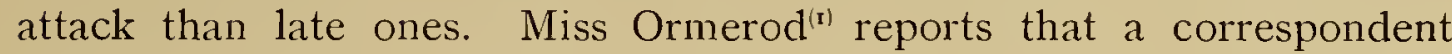
informed her that of a field of barley infested by this fly: "The field was sown in three patches, as the preceding crop of Swedes was fed off. The first patch was sown in March, and is practically free from injury. The second part was sown on April 6th, and is affected to the extent of about 2 per cent. The third part was sown on May 3 rd, and has suffered to the extent of not less than 20 per cent."

All wild grasses should be kept down.

Autumn and Winter sown crops should not be put close to fields that have been previously infected.

\section{THE PEA LEAF MINER.}

Pliytomyza pisi, Kalt.

Early in July, a Worcestershire correspondent forwarded a bundle of peashoots attacked by the larvae of this small dipterous fly, which had caused considerable damage.

The larvae had worked from the edges of the leaves towards the point of attachment to the stem. In some cases they had continued to mine into the stem itself, tunnelling down for some distance.

The larvae are greyish-white in colour and, when full-fed, about 3.5 millim. in length. In the leaves where the mining had just commenced they pupated in 32 days. Most of the larvae desert the leaves and stems and pupate in the soil; but a few were noticed in the leaves; and the flies were bred out from these.

In all probability the flies which hatch out in the early spring from the pupae mentioned above, attack wild lathyri, and it is the second brood that attacks the cultivated variety.

The most effective method of dealing with this pest, which, given favourable conditions, might become a very serious one, is to burn the haulm before the larvae pupate. Failing this the ground should be dressed with Apterite sometime during the winter.

\section{THE ORCHID MIDGE.}

Isosoma orchidearum, J.O.W.

Orchids damaged by this tiny fly have been received from a Worcestershire correspondent.

The opinion held by many horticulturists is that this fly is introduced with imported plants, Cattleya mendeli being one of the worst

(I) Man. Inj. Insects, I890, p 77. 
affected, and they recommend that all freshly imported Callleyas should be carefully examined, and if found to be affected, cleaned and fumigated.

Badly affected plants should be burnt at once, and fumigation with $\mathrm{Hy}$ drocyanic acid gas resorted to (see p. 56). The various advertised nicotine fumigants, so largely used by gardeners, are unsatisfactory.

\section{THE YELLOW WOOD WASP.}

\section{Sircr gigas, Linn.}

Not for many years past has this insect been so plentiful, and numerous examples have been received for identification, as well as damaged pieces of Firs, etc.

The female deposits her eggs in holes bored in the Fir or Spruce; and the larvae eat out a curved tumnel in the softer layers of the wood. They hibernate in these tumnels during the winter; and in the following year make their way into the deeper layers, and to the heart of the tree. The second winter is also spent in these tumnels, and early in the summer of the third year they pass to the open end of the tunnels, form a pupal chamber, which they line with a glazed coating, and there pupate.

The perfect insects emerge in July and August, either by one of the larval tunnels, or by boring a short passage through the wood.

\section{Preventive Measures.}

All coniferous timber that is weakly or damaged should be removed from the forest, etc. remain.

Stumps, broken wood, and felled trees should not he allowed to

Badly attacked trees are best cut and burnt early in the year.

\section{THE PEAR SAWFLY.}

Tenthredo corasi, Linn.

A Staffordshire correspondent reported a serious attack of this pest in August last on pear trees.

\section{LIFE-HISTORS:}

The llies appear in July; and the female lats her eggs on the upper side of the leaves of the pear and cherry. The larvae hatch out in a few days, and feed upon the upper surface of the leaves. The familiar name of shug-worm, so often applied to the caterpillar stage, is rery suitable. They are a dark green in colour, broadest at the head end and almost perfectly smooth. They possess ten pairs of feet. In four to six weeks they hecome full-fed, and catst their skins. They are then 
a yellowish colour. They now leave the leaves and in the ground spin a silky cocoon, covered outside with soil, here they pupate and remain until the following July.

\section{Preventive and Remedial Measures.}

Wherever an attack of this insect has been experienced the surface soil should, in so far as possible, be turned over in order to bury the pupae.

Respecting sprayfluids, lime water and tobacco-water have been recommended, but I have found nothing better than two applications of V2 Fluid, the second application to follow in a day or two after the first.

Dusting the trees twice with slaked lime, as a fine powder, is often effective. Here again the second application should follow the first in a day or so. 


\section{PARASITIC DISEASES OF ANIMALS.}

\section{RED WORMS.}

Sclerostommm armalmm, Duj.

A Warwickshire correspondent wote describing a disease his horses were suffering from in February last. A visit was paid to the farm, and a careful inspection made of, and a Report upon the same.

The cause of the clisease was a small nematode worm, commonly" known as "Red Worm," the "Red Strongyle," or the "Armed Sclerostome." It is a common parasite in this country and throughout Europe.

\section{LiFE-HISTORY:}

The eggs of the worm pass from the horse, and either on damp ground or in water they develop in two or three days into tiny white worms. Should the eggs fall on to dry ground they will retain their vitality for some weeks.

The embryos are taken into the intestinal canal of the horse, either in the drinking water, or off damp grass. On reaching the intestines. they commence to burrow their way into the mucous membrane of the intestinal wall and ultimately pass into the blood system. They are now carried with the blood stream, and on reaching the main arteries form an aneurism-swellings caused hy thickening of the wall of the ressel.

These swellings vary in size from that of a pea to a man's head, but average that of a wahnut.

In the clot of blood occupring each swelling the embryo worms live. By this time they have developed to a length of about fiveeightles of an inch, and now assume a pink or reddish colour.

The fact of the formation of these aneurisms is what constitutes this parasite so serious a danger, for, owing to clots passing from the sweflings, small arterial hlood ressels hecome hlocked. Short and violent colics often cusuc from this cause, or the small blood ressels mal rupture and catuse the death of the animal. Owing to the diminished hlood smpply to the intestinal region chronic indigestion troubles are set up.

CItimately the parasites are carried by the blood stream to the walls of the intestines again, and hurowing back they reach the suhmucous lityer, where they form eyst-like munours, varying in size from that of a pin head to that of a hatel-nut. Here they remain for some time, finally escaping by a hole at the stmmmit, and passing into the 
large intestine (caecum or colon) where they become mature. After the female has deposited her eggs in large numbers, both sexes and eggs are passed out of the animal's body with its excreta.

\section{Preventive and Remedial Measures.}

Prompt action is very necessary when an animal shows any symptoms of being attacked by this parasite.

The animal should be immediately stalled and all excreta burnt. The stall should be frequently and thoroughly cleansed with Cooper's Fluid.

As regard vermifuges, Thymol given in 15 gram doses in milk seems to be the only satisfactory one. A dose should be given on two consecutive mornings, the last being followed in three or four hours by a dose of castor oil.

Thymol sometimes causes bleeding from the animals nose, but nothing of a serious nature. More frequently when a horse is badly attacked and reduced owing to the parasites, a partial collapse may follow the use of this drug. A stimulant should be administered in such cases.

It is important to bear in mind that the eggs of this parasite may very easily be distributed on dirt on implements, men's boots, etc.

In pastures where affected horses have been, sheep should be put.

Care should be taken to see that only pure spring water is given to the horses, and wherever an attack of "Red Worms" has prevailed, all dykes, ditches, and clrinking ponds should be well cleaned.

Cleanliness, good food, and pure water are all important.

\section{THE LIVER FLUKE.}

\section{Fasciola (Distomuml) hepatica (Linn.).}

The adult liver-fluke is a flat unsegmented worm, about an inch and a half in length, and half an inch in breadth. It lives in the bile ducts of certain animals, particularly those of the sheep, and gives rise to the disease known as liver-rot.

The liver-fluke, like many parasitic worms, is hermaphrodite, i.e., contains the two sets of reproductive organs in the one animal.

The eggs are deposited in large numbers in the bile ducts, and pass with the bile into the intestine, and ultimately escape with the faeces.

If these eggs are deposited in damp places or in water, they give rise to a free-swimming larva, which after a time (which must be within 8 hours of hatching) bores its way into the body of a small freshwater snail Limnaea truncatula. Within the body of the snail, generally in the pulmonary chamber, the larva develops into an elongated sac-the, 
sporocyst, within whose body are produced a second generation known as redica, these force their way out of the sporocyst and now wander about the hody of the smail.

The next change is that in the bodies of these redicac a series of tailed forms known as corariac are formed, they escape, and then work their way out of the snail, and as this snail is amplibious, and is often found outside the water, the cercariac may be set free either in the water or on the grass. On the grass they lose their tails, hecome encisted, and are swallowed by the sheep with the grass. In the stomach of the sheep they escape from their cysts and make their way into the bile ducts, and in about six weeks time hecome fully developed liver-flukes.

\section{Prevention and Treatment.}

Wherever rot is found amongst a flock of sheep it is better to send them to the butcher at once. If this is not practicable, they should be moved on to well-drained, dry ground, and given a daily allowance of salt, and plenty of dry mutritious food. It is not advisable to leave sheep for any lengthened period on the same pasture.

Livers of affected sheep should not be fed to dogs raw, but first well boiled.

Pastures known to have had infected animals on should be treated with lime, all ditches and ponds should be cleaned out, and all coarse grass, reeds, etc., should be cleared out and treated with unslaked or gas lime.

\section{THE 'GID' PARASITE.}

Tacnia caenurus, Fuch.

One of the most serious parasites affecting sheep is the larval stage of a tapeworm parasitic in its adult condition in the intestine of dogs. The disease it gires rise to is commonly termed gid, staggers, sturdy: or turnsick.

The disease has been known to flockmasters and others for nearly three hundred rears, and it is estimated that it causes an anmual loss of ten per cent in this country. In other comtries, however, it has risen to thirty and forty per cent.

\section{LIFE-HISTORY.}

A dog infected with Tacmia cacmurus-the species of tapeworm, scatters the egges and gravid segments on the ground. In moist places these may live for some weels, hut if exposed to hot, dry weather they soon dic.

Both sheep and cattle swallow some of these eggs when either drinking or glawing. Once they reateh the stomach of the host, the digestive juices dissolve the shells of the eggs and set free the embryo. 
These embryos then commence and bore their way out of the intestine into the tissues. Some make their way into the blood vessels and are carried to different parts of the body. Only those, however, continue to develop which reach the brain or spinal cord. The embryo now commences to burrow along the surface of the brain, and in a few days becomes stationary, forming a tiny vesicle or bladderworm. At first this is about one eighth of an inch in diameter, but on the twentyfourth day it is the size of a pea. By the thirty-eighth day it is the size of a cherry and the heads begin to grow, new heads appear, but none reach their full development until the end of two, or three months.

When such a brain is eaten by a dog the wall of the vesicle is digested, but the heads remain uninjured and attach themselves to the wall of the intestine and develop into adult tapeworms. In about eight or nine weeks the posterior segments of the worm become filled with eggs, and breaking away from the rest they pass down the dog's intestine.

Generally speaking, lambs and yearlings are the animals attacked, it being exceptional to find gid in animals over two years old.

Those breeds which graze close are said to be more susceptible than others.

\section{Prevention and Treatment.}

Prevention of this disease is a simple matter, but there is no treatment of any value once the animal is attacked.

Dogs attending sheep, or on the farm, should be systematically treated for tapeworms, and whilst such treatment is being carried out, they should be kept tied up and all faeces collected and burned.

The brain and spinal cord of all slaughtered sheep affected with gid should first be well boiled before being fed to dogs, or they should be burned.

\section{REPORT ON SCABIES (MANGE) IN DOGS AND HORSES.}

An enquiry from a Midland County Council respecting Scabies in horses and dogs was received in July last, and a full report furnished.

As there seems to be much misconception concerning the different kinds of Scabies in this country a brief account of these may be useful.

The disease in Man, and various mammals, known as itch, mange, scald, etc., and scientifically termed Scabies, is due to certain mites belonging to two different families, hence the disease is spoken of as Sarcoptinic Scabies and Demodecic Scabies, the former is the commoner of the two.

The Sarcopt or mite of the dog is known as Sarcoptes scabiei var. canis, and that of the horse as S.scabiei var. equi. 
Another mite Psoroples commumis var. equi, causing a similar disease, is found on the horse, and a further species-Chorioples symbioles var. equi, and C.cynotis on dogs.

The horse is therefore affected with three linds of sarcoptic scabies :

I. Sarcoptic scabies due to S.scabici var. cqui.

2. Psoroptic scabies due to P.commmmis var. equi.

3. Chorioptic scabies due to C.symbioles var. equi.

Varieties of two of these occur on the dog, and although horses can contract sarcoptic mange by contact with that animal or any other mammal susceptible of being affected with a similar form of clisease, such cases of transmission are rare.

The Dog is affected with two kinds of sarcoptic scabies :-

I. Sarcoptic scabies due to S.scabici var. canis.

2. Chorioptic scabies due to C.cynotis var. camis.

According to certain authorities the first of these can be conreyed to the pig and horse, although such cases are uncommon.

The second form of scabies is produced by a parasite-Demoder. folliculormm, which lives in the hair follicles and sebaceous glands of various species of mammals.

In the dog this gives rise to what is known as Follicular Mange, Black Mange, etc.

The parasite has been found in the horse, but is rare.

\section{THE WARBLE FLY.}

\section{Hypoderma lincota (Villers).}

Hypoderma boris (De Geer).

The Ox Warble Fly has for many years been a serious pest in this comntry. There are two species of flies - Hypoderma lineala and H. boris-and many of the accounts treating of the latter species really refer to the former. "The aggregate loss due to "Warbles" in this comntry is enormous, and las heen variously estimated at from fo to E7,000,000 per ammum.

\section{LIFE-HISTOR:}

The life-history of the commoncr species, H.lincata is now comparatively well linown.

The tly deposits her eggs upon the hair of the heast on the legs, hut they may he placed elscwhere. Ustlally there are sereral eggs together, four to six on a single hair.

The egg is ahout one-twelfth of an inch in length, and firmly attached to the hatir hy a clisper-like process.

Miss Ormerod at lirst thought that the eggss were deposited under the skin of the animal, hut later she almitted that this was contrary to facts, for it had heen pointed out by Bracy Clark that the ovipositor of 
the female is a long flexible tube, telescopic in structure and quite incapable of piercing the skin.

The animal licks off the eggs, and the larvae hatched from them are carried into the mouth by the tongue.

The maggots then pass into the gullet, and penetrate the walls and wander about in the tissues, finally taking up their position along the back, immediately beneath the hide.

They next become spiny, and at this stage commence to produce considerable irritation. A swelling now arises-the "warble" - the summit of which is perforated. Towards this aperture the tail end of the bot (on which are two spiracles or pores) is directed, and through it it breathes.

Around the bot there is now formed a quantity of pus and blood upon which it feeds, developing rapidly and undergoing. a moult, it becomes mature. By means of the spines it makes its way out of the warble-cell and falls to the ground. It there enters the pupal or chrysalis stage and in from three to six weeks time the fly escapes.

The flies usually appear about the middle of May, and on until September is well in.

H.bovis is as yet imperfectly known. It is said to lay its eggs on the skin. Other observers state that the eggs are always laid in the middle line of the back, on each side of the spine, about the region of the shoulders. But, strange to say no one seems to have found the eggs there themselves.

In a recent valuable paper Mr. A. D. Imms, ${ }^{(x)}$ who has carefully examined the evidence, states :-

"There are at least three possible courses for the life-history of the larva of H.bovis, viz :-

That the larva on hatching immediately eats its way through the hide and wanders for a short distance in the sub-cutaneous tissue. It eventually returns to the surface and gives rise to the well-known tumours or warbles (Ormerod and others).

Or, having bored its way through the skin, it wanders very extensively in the tissues of its host, frequently entering the spinal canal through the intervertebral spaces. In other instances the larvae wander to the oesophagus and become embedded in the walls. In both cases they subsequently return to the sub-cutis, and there complete their development (Koorevaar).

Or, that the larvae do not bore through the skin at all, but are taken into the throat of the ox, by means of the latter licking parts of the body where the eggs are deposited. On reaching the oesophagus they hatch out from the eggs, and slowly bore through the walls of the former. They then wander about the tissues of the animal, working their way upwards at the same time, and not infrequently effect an

(I) Journ. Economic Biology, I906, vol. i, pp. 74-91. 
entrance into the spinal canal. Eventually they reach the skin as before (Ruser and others).

Which of these possibilities comes nearest to what really takes place during the normal life-history of the larval cannot be decided in the existing state of our knowledge. It is necessary to point out that this important question can only be ascertained by means of prolonged and carefully conducted experiments male with the cattle themselves.

How long the insect spends in the larval state is at present minkown. The fact that the flies themselves are found during the summer, while the small larvae hase been found in the tissues of oxen during the winter months by Koorevaar, Koch, and the other observers quoted, seems to indicate that, during the early part of the larval history, growth is extremely slow, though the larvae may migrate a good cleal in the tissues of their host."

\section{Prevention and Treatmext.}

The preventive measures which have been found effective are :-

(1) To let the cattle have plenty of shelter.

(2) To spray the beasts with some strong smelling substance, such as carbolic acid, paraffin, oil of tar, etc.

Certain breeders inform me that if this is done, say once a week, it is an effective preventive.

As to treatment, all that can be done is to squeere the matme bots out of the warbles and destroy them.

\section{THE SHEEP FLY.}

Lucilia sericata (Meigen).

Lacilia caesar (Linn.).

There are two species of Sheep Fly which in appearance and hathits closely resemble one another.

During the hot weather they may he observed Hying about the sheep, and depositing eggs in small clusters of fiftecn to twenty in the wool.

The first egges deposited are usually laid in the anal region of the sheep, 110 clouht attracted by the odour of the faeces.

In about twenty-four hours the tiny maggots hatch out, and at hirst live in the filthy wool, but after a short time, be means of their mouth hooks, they hurrow into the skin. When full grown the matggots are ahout half-an-inch in length, maturity being reached in a fortnight or three weeks. They now drop to the ground and pupate.

A single female may laty ats many ats five hunded eggse, and as the life cyele is short, there may be at mumber of gencrations cluring the season. 
Where there are a large number of flies the eggs may be deposited on the shoulders, loins, sides, and belly.

An animal attacked may easily be distinguished by the matting of the wool, the continual wagging of the tail, and the rubbing, scratching, and biting of themselves in their endeavours to allay the irritation caused by the feeding maggots. The inflammation may be considerable, and the places attacked may have an evil-smelling semi-fluid discharge. In bad attacks the wool becomes discoloured, falls out, and fails to grow again.

Apart from this loss-the animals—and especially lambs-become much emaciated.

Dr. Stewart Mac Dougall, who has devoted special attention to this parasite, makes the following recommendations :-

I. "During the fly season let the sheep be kept as clean as possible, that they may be the less likely to attract the fly.

2. Attack is more likely on low-lying sheltered parts of the meadows, where there is moisture and rank growth, than in the open.

3. Let the neighbourhood of any wounds be dressed with something that will prevent the female from egg-laying-for example, paraffin.

4. Careful and repeated inspection to ensure that the attack will be dealt with as soon as possible, so that the maggots being killed, succeeding generations are made impossible. It will be remembered that potentially a maggot may represent four hundred succeeding flies.

5. Isolate diseased sheep.

6. Where the maggots have bored into the flesh, and the wounds are deep, the sheep should be killed, or, as treatment is difficult, let a veterinary surgeon be called in.

7. The maggots are not difficult to kill. Where seen they should be picked off, or where they have got to work let the wool be shorn a little, and the parts dressed with turpentine and rape-oil in equal parts, or benzine or carbolic acid should be sprayed over the places." 


\section{APPENDIX A.}

\section{Instructions for esing Hydrocyanic Acid Gas.}

This, the most powerful and dangerous poison used in combating insect pests, should on no account be used by uninstructed or careless people.

The materials required are a 2 lb. pot jam-jar, in which place 7 ozs. of water, to which add + ozs. of sulphuric acid and, as directed below, 2 ozs. of 98 per cent. cyanide of potassium for every r,ooo cubic feet of space.

First make the room to be fumigated as air-tight as possible, leaving one window to open from the outside. Then wrap up the pieces of cyande in blotting-paper. Having placed in the jam-jar the water and acid, place the jar just within the room to be fumigated, draw the door nearly to, and with the arm reach in and drop the wapped-up cyanide into the jar, and close the door immediately. Strips of palper well simed should then at once be placed orer the crevices.

The room should remain closed for from two to three hours; then open the window from the outside, and leave until thoroughly well ventilated. Remember the fumes and the cyanide are deadly poison. Cire should be tiken that no one remains ontsicle the door of the room as in a passage, as some of the fumes might escape.

In conscrvatories, greenhouses, etc, proceed as follows :-Add the + ozs. of sulphuric acid to the 7 o\%s. of water in a jar; then take the cyanide, which should be wripped up in blotting paper, and by me:uns of a stick or piece of string drop it into the water from the outside of the greenhouse. The window or cloor should then be shut, and the house should remain closed for three-quarters of an hour at least, after which time they can be opened to ventilate, butit should he remembered that it is unsafe to enter the house until an hour or more after the windous and doors have been opened. The best results have heen obtained at a temperture of $50^{\circ} \mathrm{F}$., about one hour after sunset, when the foliage is clry.'

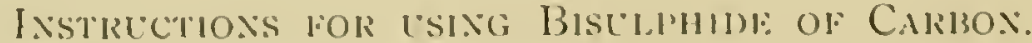

The fumes of this chemical, in addition to heing deadly poison to all animal life, are also highly inflammahle. No light-such, for instance, ats a lighted cigat or pipe-should be brought near it, 110 should it he used where there are electric wires.

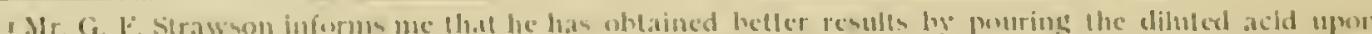

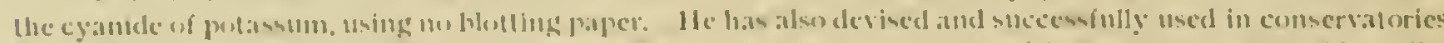
Ee a scries of fans, combling of bouds stepended ly twe cords with a strmg at eith vide. The

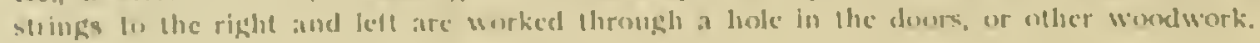


For fumigating stores it is best used in a large air-tight tin, into which the goods are placed, and then pour the bisulphide into a saucer placed upon the goods in the proportion of one pound ( $\mathrm{I}$ lb.) to every thousand $(\mathrm{I}, 000)$ cubic feet of space. The liquid should be poured out quickly in order not to inhale the fumes-there is no danger in inhaling a small quantity - and the bin closed and liept shut for at least five hours, after which time it should be well ventilated, as also the fumigated goods.

\section{APPENDIX B.}

For the benefit of those possessing no special knowledge of Entomology, it may be well to point out that, with a few exceptions, all insects are hatched from eggs. From the eggs, the larvae or caterpillars hatch out, and after a time these change into pupae or chrysalides, each ultimately developing into an imago.

The Eggs.-These are exceedingly variable in shape, size, and colour. They may be laicl singly or in groups. Sometimes they are protected by a gummy secretion, whilst others are fastened by a short thread. The food of the young in nearly all cases determines the place where the eggs are deposited, such, for instance, as on leaves, close to or in roots, in blossom buds, beneath the bark of trees, on cattle, meat, decaying animal or vegetable matter. The number of eggs laid by a single insect may be very few or many thousands ; fifty to a hundred, however, may be taken as an average. The period of hatching, generally speaking, is not of long duration, though there are cases where they remain unhatched for a considerable length of time.

The Larra.-In a few cases this is produced alive, but usually it is hatched from an egg. The larvae of Butterflies, Moths, and Sawflies, are commonly spolien of as caterpillars, those of Beetles as grubs, while those of Flies are known as maggots.

If a larva possesses legs, the first three segments behind the head each carry a pair, which are jointed and known as thoracic or true legs. Legs may also be present on the posterior segments, but these are never jointed ; they are known as pseudopods or prolegs.

It is often very difficult to say exactly to what particular order a larva belongs, but speaking in general terms, we may say that the larvae of Butterflies and Moths exhibit the following characters: A well-defined head provided with biting jaws, a pair of jointed limbs on each of the first three segments behind the head, a pair of pseudopods on the sixth, seventh, eighth, and ninth segments, making a total of sixteen. The "Looper" caterpillars have pseudopods on the ninth and twelfth segments, making a total of ten. The caterpillars of a few months are footless. 
The larvae of Beetles possess a well-defined head and biting jaws, and a pair of jointed legs on the first three segments behind the head (Rose Chafer) or legs are entirely absent (Garden Weevil).

The lawate of Flies (Diptera) are generally legless and usually the head is merged into the thorax; some, however, possess pseudopods and a head.

Those of the Hymenoptera (c.g., sawflies, wood waisps, etc.) hatie six, eighteen, or twenty-two appendages, and in sawfly larvat the second ahdominal segment ahways has a par of pseudopods; in some cases (wood wasps) the limbs are vestigal, while in other calses they are absent.

The larval stage is usually the one in which the insect does the greatest amount of damage; they feed roraciously, the daily consumption of food often exceeding many times the weight of the larra. With a plentiful supply of food they rapidly increase in size, and, as the chitinous shin is only capable of a limited expansion, it ultimately splits, and the larva comes out with a new; and sometimes differently-coloured skin. This process, linown as moulling, usually talies place five times, but the number is variable; $2,3,4,5,7,10,11,12$, and even 20, 25, and 30 moults are known in different insects. The larva is now said to be full-fed, and it changes to a pupa or chrysalis.

The duration of the larval period is subject to much variation: sometimes it is only a few days, while in other cases it may last for months or even years.

The Pupa.-The full-fed larva generally either buries itself in the ground (Rose Chafer), forming a cell of earthy particles, or spins a silky cocoon (Codling Moth), in which it changes to the pupal condition. After a time the pupal carse containing the insect craclis or splits, and the perfect insect or inngo creeps ont.

The Imago. - This is the fully-formed insect, and maty be deseribed ats an animal consisting of thirteen segments, hreathing hy tracheal tubes, with a single pair of feelers, and having the hody divided up into three distinct regions-head, thoma, and abdomenthe three segments of the thorax each carying a pair of jointed legs.

On reaching the imago stage, the paring of the sexes is soon effected; the female then lays her egges, and shortly alterwatrds dies, the generalion or life-crele heing thus completed. In some catses the perfect insect only lives a few hours or clays, hut in others they hibernate during the winter, and lay their eggs in the following springs.

Before the depreditions of any particular species of insect eatu be effectively dealt with, it is important that all the stages and rariations of the life-cyele should be clearly and thoroughly molerstood. 


\section{INDEX.}

\section{A}

Abraxas grossulariata, 36 .

A grotis exclamationis, 38.

Agrotis segetum, 37.

Anthonomits fomornm, $3 \mathrm{I}$.

Aphides on apple, 24 ; hops, 23 ; plums, 20 ; willows, 24.

Aphidins silencs, 20.

Apli is pruni, 20.

Apple attacked by Aphis, 24; Apple Sucker, 29; Ermine Moth, 39 ; Leat Miner, 39 ; Weevil, 3 I ; Wood Leopard Moth, 35.

Apple Blossom Weevil, 3 I.

Apple Ermine Moth, 39.

Apple Leaf Miner, 39.

Apple Sucker, 29.

Apterite, I9.

Aplerococcus fruxiui, 23.

Arsenate of Lead, $7 ; 34$.

Ash attacked by Gall Gnat, 4 I ; psylla, 30 ; Scale, 23

Ash Cauliflower Gnat, 4I.

Ash Psylla, 30.

\section{B}

Barley attacked by Gout Fly. 44 ; Frit Fly, 43 .

Beech attacked by Scale, 23 .

Big Bud, Io.

Bisulphide of Carbon, instructions for using, 56 .

Black-Currant Gall-Mite, Io.

Brassy Willow Beetle, 34 ; life-history, 34 ; preventive and remedial measures, 34.

Brown Currant Scale, 22.

Brown Scale, 22.

Bruchllus pisi, 3 I.

Bruchus rufimanus, $3 \mathrm{I}$.

Bulb Mite, 20; preventive and remedial measures, 2 I.

Cabbage Gall Weevi], 3I.

Carrot Rust Fly, 43 .

Cattleya mendcli, 45 .

Cecidomyia rosaria, 42.

Celery attacked by the larvae of the Garden Swift Moth, 35 .

Centhorliynchus assimilis, 32 .

Ceuthorhyncluis sulcicollis, $3 \mathrm{I}$.

Chcimatobia brumata, 36 .

Chlorops taeniopus, 44.

Chorioptes cynotis var. canis, 52.

Choriopies symbiotis var. equi, 52 .

Chorioptic Scabies, 52.

Cigar Beetle, 34.

Clover attacked by Eelworms, 19.

Cryptococcus fagi, 23.

Cryptorliyncluss lapathi, 33.

Currant attacked by Currant Moth, 36 ; Gall-Mite, ro.

Currant or Magpie Moth, 36 .

\section{D}

Dactylopius citri, 23.

Dactylopins longispinus, 23.
Demodecic Scabies, $5 \mathrm{I}$.

Dimodex folliculorum, 52 .

Diflosis pyrivora, 42.

Dogs infected with Tapervorm, 49.

Eelrvorins, I7.

Experiments with the Black-Currant Gall-Mite, Io ; Eelworms, I7 ; Insecticides and Fungicides, 7.

Eriophyes grossulariae, 20.

Eriopliyes ribis, Io.

Fasciola (Distomum) hepatica, 49.

Felted Ash Coccus, 23.

Felted Beech Coccus, 23.

Follicular Mange, 52.

Frit Fly, 43.

Fruit Pests, IO ; 20 ; 22 ; 24; 29 ; 3 I ; $35 ; 36 ; 37 ; 39 ; 4$ I ; 42; 46 .

Fruit Tree Root Louse, 29.

Fumigation of the Soil, I7.

Fumigating with bisulphide or carbon, 56.

Fumigating with hydrocyanic acid gas, 56.

Fungi Injurious, 4.

Fungicides, 7 .

Galerucclla lincola, 34 .

Gall Midges, 4I ; 42.

Garden Swift Moth, 35 .

"Gid" Parasite, 50 ; life-history, 50 ; prevention and treatment, $5 \mathrm{I}$.

Gooseberries attacked by Gal]-Mite, 20 ; Scale, 22.

Gooseberry Gall-Mite, 20.

Gout Fly, 44.

Grease Banding of fruit trees, 37.

Great Yellow Underwing Moth, 38; life-history, 38 ; remedial measures, 38.

Harvest Bug, 2 I.

Heart and Dart Moth, 38.

Hipialus lupuliuns, 35 .

Hop Aphis, 23.

Hyacinths attacked by Mites, 20.

Hydrocyanic Acid Gas, instructions for using, 56 .

Hylobius abielis, 32.

Hypoderna bovis, 52 .

Hypoderma lincata, 52 ; life-history, 52 ; prevention and treatment, 54 .

Hyponomcuta malinella, 39.

\section{I}

Inms, A. D., quoted 53 .

Injurious Fungi, 4.

Insecticides, 7 .

Insect Parasites of Insects, 20.

Introduction, I.

Isosoma orchidearum, 45 .

\section{$\mathbf{L}$}

Lachulus viminalis, 24.

Lambs attacked by "Gid," 50. 


\section{IXDEX.}

Lappet Moth, 35, life-histors, 36 .

Lasiocampar uncicifolar, 35.

Lasioderma lestacia, 34.

lassiofleral rubi, +t.

Lecullinm himisthericum, 22.

lecollum persical rar. corylii, 22.

Lees, J, cited, 42.

Leplus anlmmmolis, 21.

Lime and Salt Spratyfluid, 7.

Liver Fluke, 49 ; life-listory, 49 ; prevention and treatuent, 50 .

Lucilin cereserr, 5t.

Jencilia servalu, 5t; life-history, 5t.

bourelia ilerkella, 39.

\section{M}

MacDougall, Dr. Stewall, quoted 5.5.

Mange (see Scabies).

May Bus, 30.

Meade, Dr. cited, 41 .

Mealy Bugs, 23.

Newstead, Robert, cited, 23.

o

Oats attacked by Eelworms, 19; Frit Fly, +3.

Oliphaint, P. Blair, Report on treatment for "Bius Bud," I2.

Onion Fly, 42; life-bistory, 42; prerentive and remedial measures, 4.3 .

Orchard Inspection, 3.

Orchid Midge, 45 .

Ormerod, Miss E. quoted, 45 .

Oscinus tiol, 43 .

Osier Viecril, 33: life-history, 33; remedial me*isures, 33.

Parasitic Diseases of Animals, 48.

Peal Aplise, 20.

Pe:il lBectle, 31 ; life-history, il ; prerentive and remedial meatsures, 31.

Pual Lceall Mince, 45.

Pe:l Thins, 21.

Peas attalcted by Bectles, 31: Ical Mince, 45; Thrips, 21.

Pear Midge, +2.

l'car S:molly, $4^{6}$; life-history, fo ; preventive and remedial measules, 47 .

phorhia ceparmin, 42 .

P'horosion limmoli, $2 \mathbf{3}$.

Pliflodecla aitillimac, 34

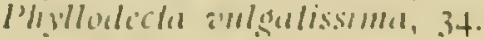

l'hilloperlha horlicula, 30.

l'hyomina pisi, 4.5.

line llecvil, 20 ; life-listory, 20; preventive and renuedial me:asures, 21.

Plum Aris, 20.

julle resile, +3.

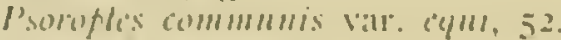

Psilla travimi, 30.

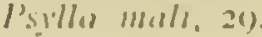

\section{$\mathbf{R}$}

R.1spberere (iall Midge, al ; life-historv, t1: prevente and rensedial uncers111'ch, 41 .
Red Wolms, 48 ; life-listory, 48 ; Merentive and remedial méasures, 49 .

Rhizoglyphus iehimopus, 20.

Riley, Charles V., quoted, I.

Root-knot Discase, 19.

Rye attacted by Gout Fly, t+.

\section{S}

Sanderson, L. Dwight, quoted, I.

Surcuples seabici rar. cands, 51 .

Sarroples scabici val. cyui, 5l.

Sitreptinic Scaties, 51 .

Scabies (.Mange) in Horses and Dogs, 51.

Scalce Insects, 22;23.

Sillizullutal folliells, 29.

Schizonema lanigera, 24.

Sclicostommm armalmm, 48 .

Sheep Fly, 54 .

Siphomophora pisi, 20.

Sirex sigus, to.

Soil Fumigation, 17.

SprayHuich, 7 .

Stedman, J. M., quoted, 26.

Strallsoll, G. F., cited, 56.

Strawbery plauts altacked by larvac of Garden Swift Moth, 35 .

\section{T}

Tacmin carmurns, 50.

Telllurede cerrsi, 4 o.

Theobald, IF. V., cited, II; 30.

Tomatoes attacked by Eelworm, 19.

Thrips pisizora, 21.

Triflesema frombla, 38.

Trombirlum holosericimm, 21.

Tulips attaclicd by Mites, 20.

Turnips attacked by Dart Moth, 37: Weevil, 32.

Tumip Dart Moth, 37.

Turnip secel lleweril, 32.

Vi liluid, 7 .

Visporite, 20; 37.

Veugetable Harrow attacked hy EelWorllls, I().

Warhle lily, 52.

Wheat allacked bo Goul lils, +t

IVillow allacked by sphis, it; heutles, 3.3 : wall-midge, 42.

Willow Aplis, 24.

llillem Bectles, .3.3.

Willow Midse, +2.

Winter Bealls altatederl hy latrile of Giucken siwit Mnth, 35

Winter Moth, jo.

llinter Spraying value of, $2: 23 ; 3 \%$

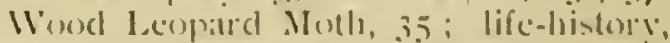
$3.5 ;$ preventive and rencedial ments111.'s is.

Moolly Aplis, 24 ; life-histors, 24 ; pec-

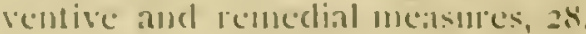

\section{$Y$}

Pellow Wrod 11 issp, fo; life-hintors,

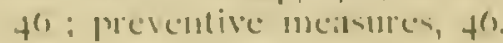

\%encimar aesum, 35. 


\section{HORTICULTURAL REQUISITES.}

"GISHURST COMPOUND"

For preventing and destroying Red Spider, Green Fly, \&c. Harmless in use. Its soluble sulphur, \&c., has for 40 years cured blights and fungus

on plants. It is also useful for washing unhealthy dogs.

\section{"GISHURSTINE"}

For the protection of Boots and Shoes from damp, ensuring comfort and health to the wearers. Boots treated with Gishurstine take polish. It is also good for use on harness.

\section{SOFT SOAP}

Specially prepared as an insecticide, including

"SOFT SOAP and Quassia." " SOFT SOAP and Paraffin."

To be obtained from all dealers in Horticultural Requisites, or Wholesale from

PRICE'S PATENT CANDLE COMPANY, Limited, LONDON, LIVERPOOL and MANCHESTER.

\section{SPRAYING APPARATUS, SPRAY FLUIDS,}

\section{Insecticides \& Fungicides,}

\section{A SPECIALITY.}

\section{LIVERSIDGE, \\ Horticultural \\ Sundriesman,}

41, High Street, EVESHAM. 


\section{WIREWORMS}

GRUBS, TOODLICE, LEATHEIRTAKETS, ANTS, BEETLES, JULLS WORMS, EELITORMS, CENTIPEDES, MILLIPEDES,

PEARMIDGE, and all similat insects in the soil can readily he destroyed by

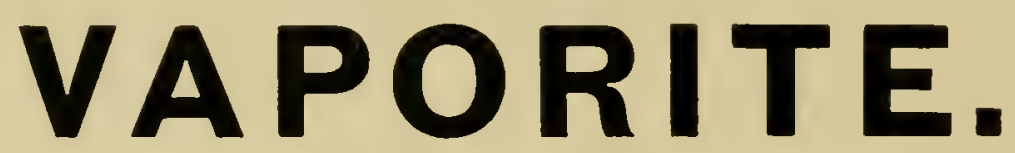

The annual loss sustained hy growers from the ravages of insects in the soil, if it could be ealeulated, would form an amakins total.

These insects in the soil can readily be destroved hy VAPORITE-a material which is very inexpensive and tery readily applied to allmost all crops.

The process usually consists of distributing the V'APORITE upon the soil and then digging it well into the ground beneath the insects. The VAPORITE gras rises and destroys the insects.

VAPORITE is a srey powder-it is non-poisonous and no special implements are required for its use. Full directions are sent with each consignment.

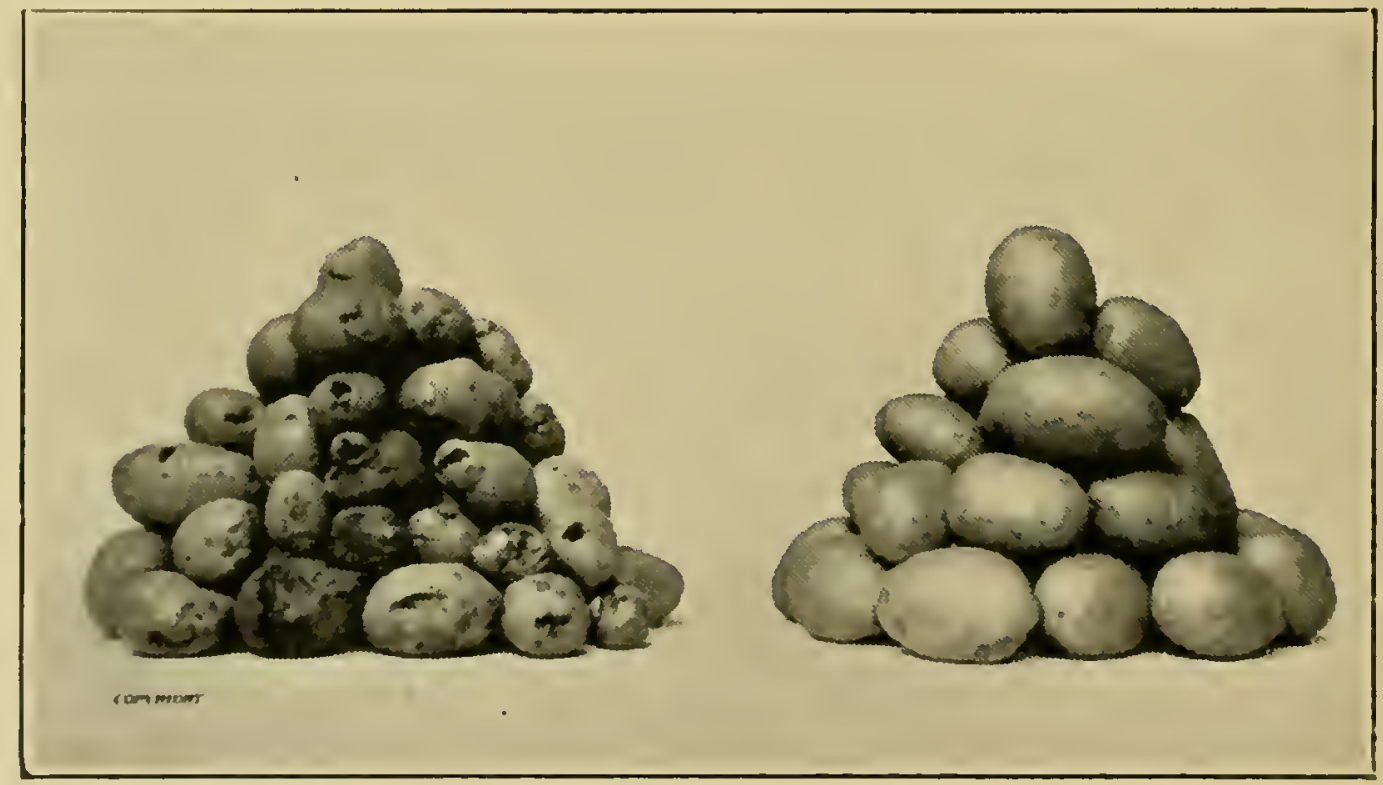

NOT USING YAPORITE.

USING VAPORITE.

Above photo was taken from the actual crop without any modification.

SPECIMEN EXTRACTS OF TESTIMONIALS:

CARROTS.

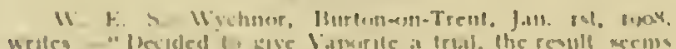

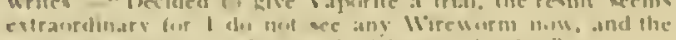

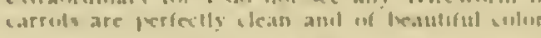

PEARMIDGE.

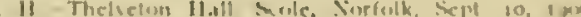

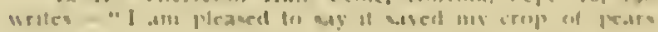

TOMATOES.

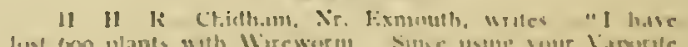

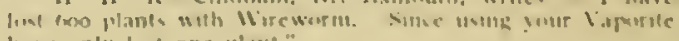
liste only liont ante plation

CUCUMBERS.

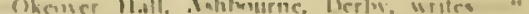

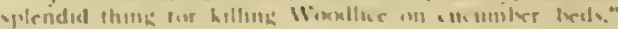

\section{VAPORITE, Price}

11/6 Per Cwt.

CARRIAGE PAID.

E9 15/ Per Ton.

ASK FOR NEW BOOKLET NO. $14 \mathrm{~A}$.

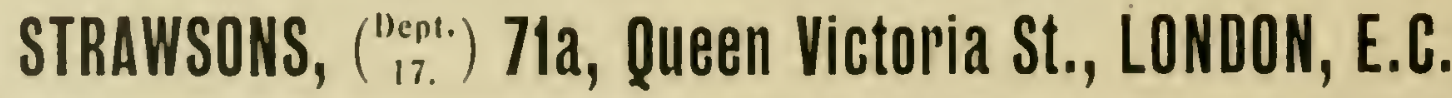




\section{INSECTICIDES, Etc.}

(Sec also opfositc page.)

\section{SODALIN.}

A concentrated Antiseptic Winter "Wash" for destroying Moss Lichen, Codling Moth, American Blight, and all insects which live in the bark of the trees in Winter.

Sodalin is a great improvement upon the old-fashioned Winter "Washes." Its effect upon the trees is remarkable.

\section{STRAWSONITE.}

A concentrated Bordeaux mixture, guaranteed $\mathbf{9 8} \%$ pure, containing as much metallic copper as $\mathbf{9 8} \%$ pure Sulphate of copper itself.

This Fungicide has been used on a very large scale in England for the last i5 years. It is the original material which popularised Potato spraying in the British Isles.

\section{SULPHATE OF COPPER.}

Guaranteed $98 \%$ pure, immediately soluble. By special process our Sulphate of Copper is rendered immediately soluble on cold water-it is altogether superior to the ordinary finely ground or powdered Sulphates.

The Charlock spraying process introduced by Strawsons into England in 1898 has been of great assistance to thousands of farmers troubled with Charlock, or Yellow Weed, in their Corn.

As it was found that the ordinary Sulphate of Copper was very inconvenient for this process this special brand was put on the market.

\section{OTHER INSECTICIDES, Etc.}

The HOUSE of STRAWSONS, established over a quarter of a century, concentrates its attention exclusively upon such products and is the largest of its kind in the World.

\section{STRAWSONS, ( $\left.\begin{array}{c}\text { Dept. } \\ 17 .\end{array}\right)$ 71a, Queen Victoria St., LONDON, E.C.}




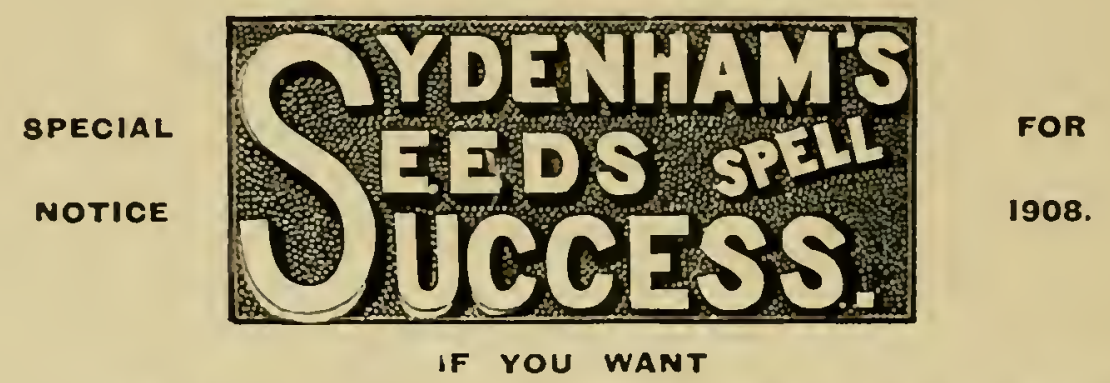

REALLY GOOD BULBS AND SEEDS

AT MODERATE PRICES, send to

MR. ROBERT SYDENHAM,

TENBY STREET, BIRMINGHAM.

No one will serve you better.

HIS UNIQUE LISTS
sent post free on application.
Are ncknowledged by all to be the Best, Cheaprest, and most Reliable ever
jublished. They contain only thie liest

\section{VEGETABLES, FLOWERS AND BULBS WORTH GROWING.}

Being the Sulections of the Iargest Seed Growers, Market Gardeners, and the lnost celebruted Professional Garieners and Anintens in the lingdon. They also contain very useful cultural instuction.

\section{SWEET PEAS A SPECIALITY.}

Xu fowers give so nuch cht hlomm at so. little const and uonble if treated as insturtions sent with each collectim.

12 good varictics, 50 secds of cach in separate packots, 18. 6d; 12 better varictics, 50 secds of each, 18. 9d; or the Two Collections for 28. 6d.; a Third Collection of the 12 best varictics, 80 sceds of each, 28 ; or the Threc Collections, 48. post frec, and a Packet of the four best striped and four other varletics free of charge; tho best and chcapest Collection ever offered, at about One Penny a Packet.

THE BEST TOMATOES, 3d. per packet of 200 sceds.

THE BEST CUCUMBERS, Gd. per packet of 10 sceds.

THE BEST ONIONS FOR EXHIBITION.

EXCELBIOR, 6d. per packet of about 1,500 secds. AIlsa CRAIC, 6d. per packet of about 1,200 8ceds.

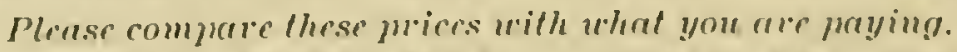

ALL OTHER SEEDS EQUALLY CHEAP AND COOD.

Mr SYDENHAM'S SEEDS AND BULBS havo been represented and Eaincd as many First Prixe at London, Birmingham, Cardiff, Preston. Edinburgh, Newcastlc-on.Tyne, Plymouth, Hanloy, Shrowsbury, Taunton, Wolverhampton, \&c., \&c., for the past twolvo years, as any firm in England

FULL LISTS POST FREE ON APPLICATICN. 


\section{STANDLEY BELCHER \& MASON, Ltd., LUDGATE HILL, BIRMINGHAM.}

Telephone No. 3825. Telegrams-"Laboratory, Birmingham." Contractors to most of the largest institutions and works in the country.

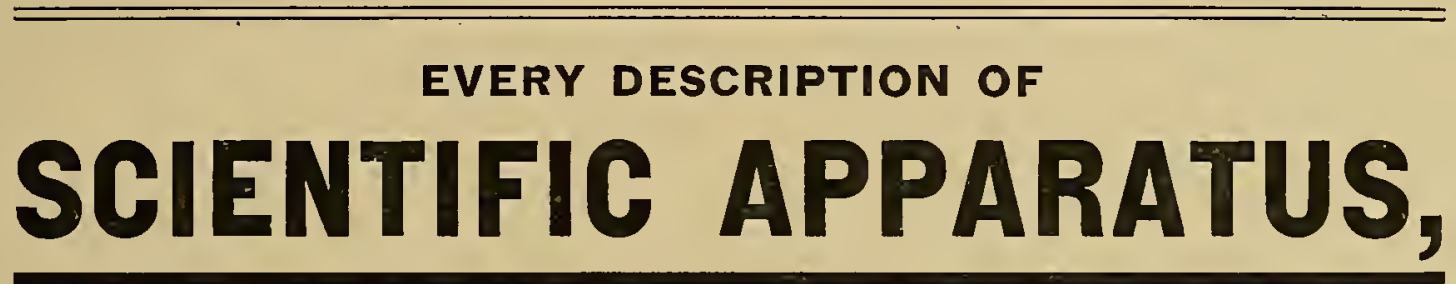
AN D

\section{PURE CHEMICALS FOR ANALYSIS.}

(Good Stock of Kahlbaum's and Merck's make.)

Our PURE ACIDS are made at our own Acid Works, Hooper Street, and are free from the impurities found in many so=called Pure Acids.

BALANCES with agate knife edges, so fitted that should they be damaged they can be replaced in a few minutes without returning to the maker.

MICROSCOPES-Leitz, Zeiss, Reichert, and other makes.

GLASS WARE-Jena $(R)$ and Josel Kavalier's make in stock.

PURE SILICA WARE, opaque and transparent.

PORCELAIN-Genuine Royal Berlin (Sceptre mark), and other makes.

GRADUATED INSTRUMENTS, "Normal," highest accuracy.

FINEST QUALITY, REASONABLE PRICES.

ORDERS HAVE THE PERSONAL ATTENTION OF THE PRINCIPALS.

CATALOGUES FREE UPON APPLICATION.

SULPHUR, SULPHATE OF COPPER, LIME, QUASSIA, Etc., for Horlicultural Purposes. 


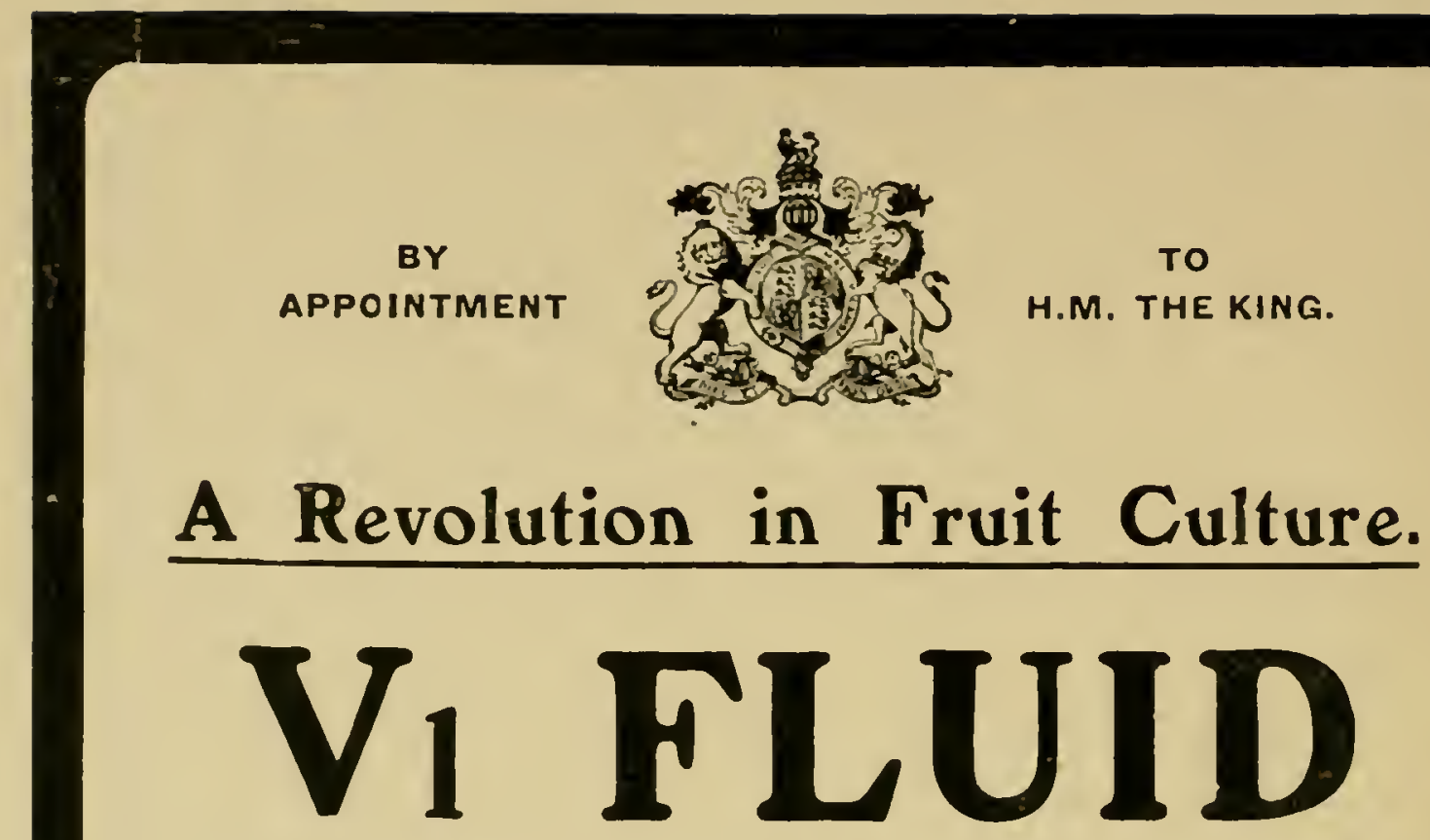

The WINTER SPRAY-FLUID, Kills the eggs of Insects and Mites, and the spores of Fungi.

MR. W. EDMONDS, of Rede Court, Strood, Kent, airilis:-

"The benefits of $V 1$ fluid were simpiy marvellous. The trees sprayed with it were clean, free from insect pests, and from all mosses and lichens, the foliage was beautiful and the fruit as perfect as I ever expect to grow it, while on the unsprayed trees the condition of both the foliage and the fruit was so inferior that one could hardly believe the fruit was grown in the same orchard. I am quite sure that the V1 and $V 2$ fluids manufactured by Messrs. Cooper, of Berkhamsted, are a very long way ahead of anything which has ever before been introduced to the fruit-grower. "-Kinlish Guailli.
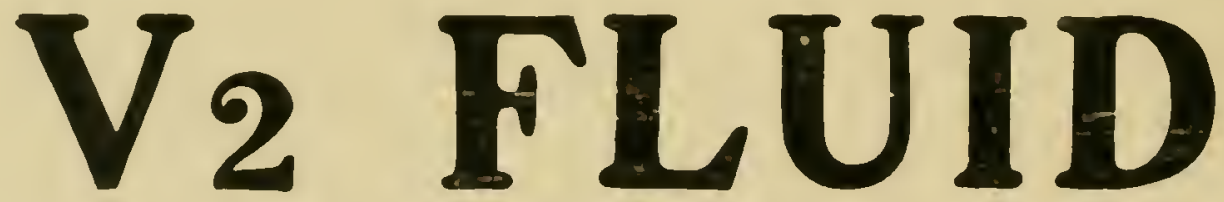

The SUMMER SPRAY-FLUID, is deadly to Aphis, Psylla, and scale Insects, and does not injure Leaf or Blossom.

Send for Free lBooklet,-" THE SPRAYING OF FRUIT TREES." which slves full partlculars of these wonderfut Insectleldes.

Manufactured by

Wm. COOPER \& NEPHEWS, Berkhamsted, England. 



\section{INSTRUMENTS Mim 00028103554}

OF

\section{ACCURACY AND PRECISION ARE}

DESCRIBED AND ILLUSTRATED

IN

LABORATORY REQUISITES,

CHEMISTRY, VOL. 1.

The following Sections aRe deAlt With :-

Agricultural Analysis, Bacteriology, Cement Testing, Brewing,

Cas Analysis, Meteorology, Microscopy,

Mining, Spectroscopy,

etc., etc.

PHYSICAL INSTRUMENTS ARE DEALT WITH

IN A SEPARATE VOLUME.

THE ABOVE

WILL BE FORWARDED FREE

TO

PRINCIPALS,

PROFESSORS, and

SCIENCE MASTERS,

UPON APPLICATION TO :-

PHILIP HARRIS \& CO., LTD.,

EDMUnd StREet,

BIRMINGHAM. 